\title{
Yabancı Uyruklu Öğrencilerin Kültürlenme Düzeylerinin İncelenmesi ${ }^{a}$
}

\author{
Ramin ALIYEV ${ }^{1 b}$, Selahiddin ÖĞÜLMÜŞ ${ }^{2}$ \\ ${ }^{1}$ Yrd. Doç. Dr., Hasan Kalyoncu Üniversitesi, Eğitim Fakültesi - Gaziantep / Türkiye. \\ ${ }^{2}$ Prof. Dr., Ankara Üniversitesi, Eğitim Bilimleri Fakültesi - Ankara / Türkiye. \\ Başvuru tarihi: 11 Aralık 2015 Düzeltme tarihi: 04 Nisan $2016 \quad$ Kabul tarihi: 13 Nisan 2016
}

Öz

Araştırmanın amacı, farklı kültürlerden gelen bireylerin eğitim ortamlarında kültürlenme düzeylerini incelemektir. Çalışma, kültürlenmenin çeşitli değişkenler açısından ele alındığ tarama modelinde bir araştırmadır ve Türkiye'de öğrenim gören yabancı uyruklu üniversite öğrencilerinin eğitim ortamındaki kültürlenme düzeyleri incelenmiştir. Araştırma grubunu, Türkiye'ye gelen ve öğrenimlerine üniversitelerde devam eden farklı yaşlardaki, Avrupa, Ortadoğu ve Kafkasya kökenli 300 öğrenci oluşturmuştur. Verilerin toplanması için "Kişisel Bilgi Formu" ve araştırmacilar tarafindan geliştirilen "Kültürlenme Ölçeği" kullanılmıştır. Kültürlenmenin bazı değişkenler açısından farklılaşıp farklılaşmadığını belirlemek için t testi, grupları birbirleriyle karşılaştırıp farkı bulmak için de Tek Yönlü Varyans Analizi (ANOVA) kullanılmıştır. Elde edilen bulgulara göre, yaş arttıkça bütünleşme stratejisinin daha fazla tercih edildiği saptanmıştır. Türkiye'de kalış süresi, diğer gruplara göre daha az olan katılımcıların daha çok asimile olduğu görülmüştür. Kafkasya'dan gelen katılımcıların kültürlenme stratejilerinden özellikle bütünleşme stratejisini, Ortadoğu'dan ve Avrupa'dan gelen katılımcılara göre daha belirgin olarak tercih ettikleri, Türkiye'de kendi ülke vatandaşlarıyla ikamet eden kişilerin ayrılma puanlarının yüksek olduğu saptanmıştır.

\section{Anahtar Kelimeler}

Kültürlenme, Yabancı Uyruklu Öğrenci, Erasmus, TÖMER

\footnotetext{
a Bu çalışma, 2011 yılında Ankara Üniversitesi Eğitim Bilimleri Enstitüsü tarafından kabul edilen "Farklı Kültürlerden Gelen Yüksek Öğretim Öğrencilerinin Eğitim Ortamlarındaki İlk Etkileşim Algılarının ve Kültürlenme Düzeylerinin İncelenmesi"adlı doktora tezinden türetilmiştir.

b Sorumlu Yazar/Correspoding Author: Hasan Kalyoncu Üniversitesi, Eğitim Fakültesi, Eğitim Bilimleri Bölümü, Rehberlik ve Psikolojik Danışmanlık ABD, Gaziantep / Türkiye.

e-posta: aliyevus@gmail.com
}

doi : $10.18506 /$ anemon.20532

URL: http://dergipark.ulakbim.gov.tr/anemon

Copyright (c) 2013-2016 Muş Alparslan Üniversitesi 


\title{
An Investigation of International Students' Acculturation Levels
}

\begin{abstract}
The purpose of the study is to investigate the acculturation levels of individuals coming from different cultures in educational settings. The study is a survey model research in which acculturation is handled with different variables and the study investigated acculturation levels of international university students in their educational settings. The sample of the research is comprised of 300 students, in various ages, coming from Europe, Middle East and Caucasia to Turkey and who continue their education in different universities. To collect data, Personal Information Form and Acculturation Survey, developed by the researchers, were used. In order to determine whether acculturation differs or not in terms of certain variables, t- test was employed, and One Way Variance Analysis (ANOVA) was used to find whether the groups differ from each other. According to the findings, it was found out that the more the aging increases, the more the integration strategy is preferred. It was seen that participants whose stay in Turkey is lesser than the other groups are assimilated more, participants coming from Caucasia prefer integration strategyamong acculturation strategies- more obviously than the participants coming from the Middle East and Europe, and the ones who stay with their own citizens in Turkey have high separation scores.
\end{abstract}

Keywords

Acculturation, International Students, Erasmus, TÖMER

\section{GíRİs}

Yeryüzünde farklı kültürlere ait kişi, grup ya da topluluklar değişik nedenlerle (eğitim, göç, felaket, daha iyi yaşam koşulları vb.) hareket halindedirler. Kültürlerin karşılaşması ve birbirleriyle etkileşime girmesi sonucunda bireyler, gruplar ve topluluklar birbirlerinin kültürlerinden etkilenirler. Kültürlenme kavramı, belirli bir kültüre mensup kişilerin bir başka kültürden kişilerle temaslarında yaşadıkları kültürel ve psikolojik değişim süreci ya da değişimlerdir (Bilgin, 2003). Kültürlenme tanımında ifade edilen iki grubun birbirini eşit düzeyde etkilediği düşünülse de gerçekte gruplardan birinin diğerini daha fazla etkilediği gözlemlenir (Tanaka vd.,1994).

Kültüre uyum sürecinde ele alınacak olan kültürlenme kavramı; orijinal kültür içinde sonradan ortaya çıkan bir veya daha fazla grubun değişimlerle devam eden 
ilişkisini ve farklı kültürlerden gelen bireylerin aynı gruplarda ilişki sürmesinin sonuçlarını kapsamaktadır. Kültürlenme kavramı prensipte yansızdır, pratikte ise kültürlenme gruplardan birinde, diğerine göre daha fazla değişime neden olmaktadır. Kültürlenme, bir grubun kültüründe meydana gelen değişmedir ve bireyin psikolojisinde de değişiklik yaratmaktadır (Berry, 1999).

Kültürlerarası psikolojide kültürlenme kavramı ile ilgili pek çok araştırma yapılmıştır. Yapılan araştırmalarda bu başlık altında özellikle göçmen kimliği, kültürlenme tutumları, kullanılan stratejiler, vb. konular ele alınmıştır (Berry, 1994; Berry vd., 1989; Farver vd., 2002; Kim vd., 2001; Ataca ve Berry, 2002; Hovey, 2000).

Kültürlenme, kültürlerarası psikolojinin en karmaşık alanlarından biridir. Kültürlenme süreci birden fazla kültürü kapsadığı için iki ayrı anlamı vardır. İlk olarak kültürlenme; iki ya da daha fazla kültür arasındaki etkileşim sonucu ortaya çıkan durumdur. İkinci olarak, en az iki kültürün etkileşimini ve bu etkileşim sonucunda yaşanan psikolojik değişiklikleri kapsamaktadır (Berry, 1999).

Kültürlenme sürecinde geçiş her zaman kolay değildir. Geçiş evresinde birey psikolojik sorunlar yaşayabilir. Geçiş evresi aynı zamanda değişim evresidir. Üç evreden meydana gelir. İlki; ayrilma evresidir. Bu evrede birey sosyal rol ve statüleriyle ilişkisini kesmektedir. Daha sonra yeni rollere uyum sağlamak için adapte olur ve değişir. Son evre birleşme evresidir. Bu evrede birey kendini yeni rol ve statü ile bütünlemektedir (Montreuil ve Bourhis, 2001).

Konu ile ilgili bilgilendirme, politika ve program geliştirme ile riskli olan kültürlenmede geçiş süreci yumuşatılabilir (Sam ve Berry, 1995). Bu süreçte kişiler; kendilerine benzer diğerleri ile kendilerini, sahip olmak istedikleri ve hak ettiklerini düşündükleri şeyler açısından karşılaştırarak göreceli yoksunluk yaşarlar. Bir diğer değişle azınlık grup üyeleri kendi durumları ve diğerleri veya kendi gruplarının durumu ve diğer grupların durumu arasındaki farklılık algılarına dayanan olumsuz duygular yaşarlar. Bu durumla sosyal karşılaştırmalar yapılarak ve eğer varsa bunlarla, olumsuzluklarla baş etme stratejilerini kullanarak başa çıkılır (Meşe, 1999). Kültürlenme sürecinde buna benzer başka bireysel ve grupla ilgili psikolojik ve sosyal psikolojik süreçler yaşanabilir.

Bireylerin kültürlenme süreçleri incelenirken öncelikle bireylerin nereden geldikleri ve geldikleri toplumun özellikleri incelenmelidir. Çünkü bireyler toplumların değer, kültür ve sosyal sistemleri içinde ve toplumların içinde bulundukları durumsal faktörlerde şekillenirler. Eğer yerleşilen toplumla bireyin köken toplumunda edindiği kültürel özellikler uyuşmazsa, kültürel mesafe artar ve bireyi kültürlenme sürecinde olumsuz etkiler. Çünkü kendi kültürüyle yerleştĭgi kültür arasındaki mesafeyi aşması zor olur ve birey çelişkiler yaşar.

Kültürlenmenin çok boyutlu ve karmaşık olan yapısının daha iyi anlaşılabilmesi için kültürlenme grupları ve kültürlenme stratejileri ortaya konmuştur. Bazı toplumlarda birden fazla kültürel grup bulunabilir. Çok kültürlü toplumlarda kültürel gruplar arasında kültürlenmenin ortaya çıkmasını ve çeşitlenmesini Berry 
ve Sam (1997) üç faktöre bağlamışlardır. Bunlar; yer değiştirme, isteklilik ve sürekliliktir.

Tablo 1. Kültürlenme grupları

\begin{tabular}{ccc}
\hline Hareketlilik & \multicolumn{2}{c}{ Gönüllü Bağlantılar } \\
\hline & Gönüllü & İstem Dışı \\
Yerleşik & Etnik Kültürel Gruplar & Yerli Halklar \\
\hline Göçen & Göçmenler & Mülteciler \\
Kalıcı & Konuklar & Sığınmacılar \\
Geçici & (Uluslararası Öğrenciler) & \\
&
\end{tabular}

Kaynak: Berry ve Sam, 1997; Huang, 2010

Tablo 1'de görüldüğü gibi konuklar (uluslararası öğrenciler) yeni geldikleri kültürde sürekli yerleşme amacında olmadıkları için yeni kültürün kısa süreli (geçici) ziyaretçileridir. Konuk grupları heterojen yapıdadır, kültürlenme deneyimleri genellikle gönüllü ve belirli bir amaç içindir. Bu nedenle konukların göreli olarak daha kolay uyum sağlamaları beklenmektedir (Berry ve Sam, 1997).

Berry ve Sam (1997), mültecilerin geçici ve gönülsüz göç etmiş kişilerden oluştuğunu ifade ederler. Mülteciler kültürlenme öncesinde savaş, bireysel düzeyde utandırma, işkence, mahrumiyet, kıtlık gibi oldukça zor deneyimler yaşamışlardır.

Günümüzde, dünyada çok az yerli bulunmaktadır (örneğin; Afrika Cumhuriyetinde Bantuca konuşan yerliler gibi). Yerliler politik, ekonomik ve askeri olarak daha az güce sahiplerdir. Yerlilerin bir bölümü diğerleri ile istemeden ilişki kurmuşlardır (Berry ve Sam, 1997). Mülteci ve yerlilerin kültürlenme sürecinde daha fazla zorluk yaşadıkları ve risk taşıdıkları bilinmektedir (Berry, 1999).

Etnik kültürel gruplar, yerleşik, bağlantıları sürekli, genellikle gönüllü ve çoğunlukla üyeleri kültürlenme bölgesinde yetiştiği için daha az uyum problemi yaşarlar (Berry ve Sam, 1997). Etnik kültürel grupların kendi öz kültürlerinde yaşam deneyimlerinin olmamasının, uyum sürecini olumlu etkilediği saptanmıştır (Farver vd., 2002). Diğer yandan etnik kültürel gruplar, kendilerini belirli bir "biz" in mensubu olarak, diğerlerinden farklılıklarını vurgulayarak ifade ederler. $\mathrm{Bu}$ durum zaman zaman diğerlerine karşı çıkma, sınırlandırma, kendini çevrelemenin bir tarzı olarak ortaya çıkmaktadır. Sonuçta, bir tür dar cemaatçilik veya kabile varlığ yaşantısına da kayılabilir (Bilgin,1994).

\section{KÜLTÜRLENME STRATEJILERİ}

Kültürlenme kavramı, yapılan çalı̧malarda genel olarak, bireylerin ve grupların bir diğer kültür ile uzun süreli etkileşimleri sonucunda meydana gelen psikolojik ve davranışsal değişim süreci olarak tanımlanmaktadır. İnsanlar sürekli olarak 
farklı kültürel ortamlara girerek hayatlarını sürdürürler. Bu kültürel ortamlar insanların bilişini, davranış ve duygularını düzenler (Kim vd., 2001; Sam, 1992). Yani insanlar arasında sürekli sosyal etkileşim aracılığı ile değişim sürer. Bireyler aynı anda farklı kültürlerin içinde bulunurlar ve sürekli değişim yaşarlar.

Çok kültürlü topluluklarda, kültürel gruplar ve bu grupların nasıl kültürlendiği konusu oldukça önemlidir (Berry vd., 1989). Kültürlenme ile ilgili yaptığı çalışmalar sonucunda Berry, farklı kültürlere mensup birey ve / veya grupların birbirleri ile ilişkisi sonucu oluşan kültürlenme stratejilerini kuramsal bir çerçevede ele almıştır. Çok kültürlü toplumların hemen hepsinde, kültürel gruplar ve onların üyeleri, yaşamlarının her anında ve her alanında nasıl kültürlenecekleri konusu ile karşı karşıyalardır. Kültürlenme ile ilgili iki temel soruya verilen evet/hayır şeklindeki cevaba göre, dört kültürlenme stratejisi ortaya konmuştur (Berry, 1999).

Şekil 1. Kültürlenme Stratejileri

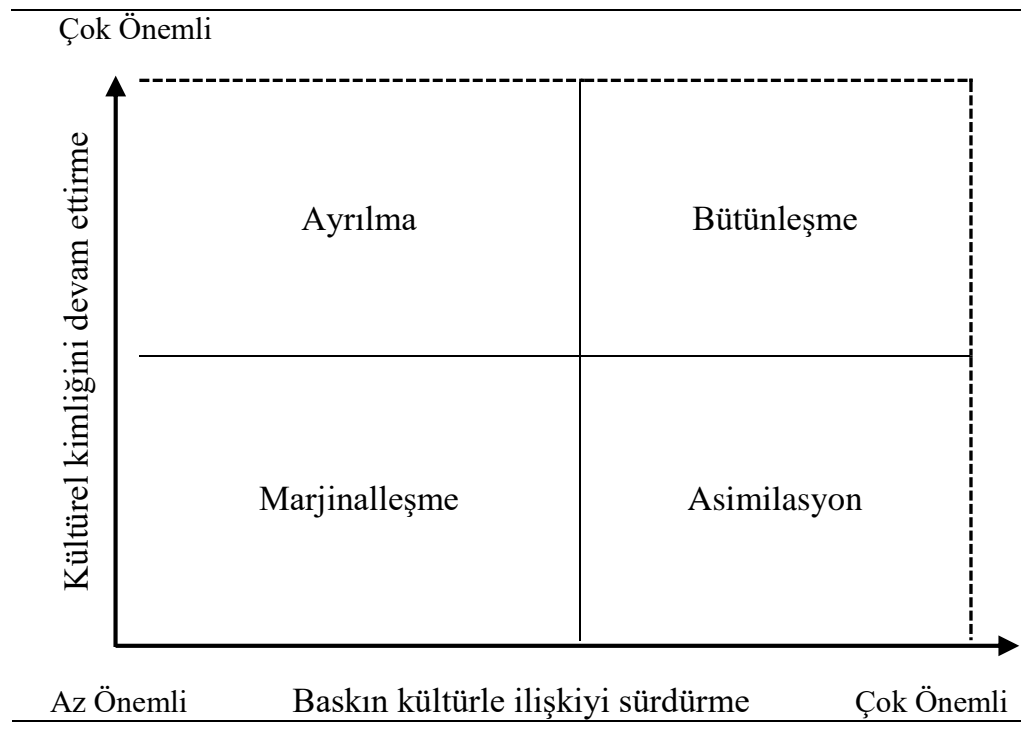

Kaynak: Berry (1999)'den derlenmiştir.

Şekil 1' de belirtilen kültürlenme stratejileri, kültürlenme sürecinde kişilerin tutumlarına bağlı olarak meydana gelir. Kişi için bir yanda kendi kültürü varken, diğer yanda göç ettiği kültür bulunmaktadır. Bu süreçte kişinin tutumları hangi stratejiyi kullanacağını belirlemektedir. Eğer bireyler kendi kültürel kimliklerini devam ettirmek istemeyip, diğer kültürlerle ilişki arayışında iseler asimilasyon stratejisi meydana gelir.

Bilgin (1994), asimilasyonu "yabancının veya göçmen işçinin davranış ve zihniyet dönüşümüyle, toplumun yaşam tarzına ve normlarına tamamıyla katılım" şeklinde tanımlayarak, asimilasyon sürecini "bir bütün içinde erime" olarak ifade eder. $\mathrm{Bu}$ 
sürecin tam tersinde ise, baskın olmayan grup kendi öz kültürünü iyice yerleştirip, diğer kültürler ile etkileşime girmekten kaçınıyorsa ayrılma stratejisi yaşanır. Bireyler, kendi kültürel özelliklerini sürdürürken baskın kültürel grupla da etkileşime girmeye eğilimli iseler o zaman bütünleşme stratejisi ortaya çıkmaktadır. Bu stratejide birey, bir yandan göç ettiği toplumda daha geniş bir sosyal ağın parçası olmaya çalışırken, diğer yandan da kültürel bütünlüğünü o topluma uyarlayarak sürdürür.

Kültürlenme stratejisi olarak; bütünleşme stratejisinde, birey kendi kültürel özelliklerini sürdürürken, baskın kültürel grupla da etkileşime girmeye eğilimlidir. Ayrılma stratejisinde, birey baskın olmayan kendi öz kültürünü iyice yerleştirip, diğer kültürler ile etkileşime girmekten kaçınır. Asimilasyon stratejisinde ise, bireyler kendi kültürel kimliklerini devam ettirmek istemeyip, diğer kültürle ilişki arayışındadırlar (Berry, 1992).

Berry (1992), bütünleşme kavramını "bir toplum üyelerinin bir değişim ilişkisinde karşılıklı bağımlılığın üyelerin ortak değerleri ve işleyiş kurallarına katılımının ifadesi" olarak belirtir. Bütünleşme kavramını bir bütünün parçası haline gelme şeklinde ortaya koyar. Son olarak kişi hem kendi kültürüne hem de göç ettiği kültüre az ilgi duyuyor ve sürekliliğine ilgi göstermiyorsa marjinalleşme stratejisi ortaya çıkmaktadır. Kişi yeni kültürel çevrede kendi tutum ve davranışlarına uygun strateji tercihleri ile kültürlenir.

Başka bir ifadeyle, kültürlenme stratejileri etkileyen ya da etkilenen gruba göre değerlendirilir. Baskın olmayan (non-dominant) gruplar açısından, bireylerin kültürel kimliklerini devam ettirmek istemedikleri ve diğer kültürlerle günlük etkileşimde bulunmayı istediklerinde, asimilasyon (assimilation) stratejisi oluşmaktadır (Berry, 1997). Yani asimilasyon, yeni kültürün lehinde orijinal kültürden vazgeçmektir (Palumbo ve Teich, 2004). Gronhaug vd. (1993)'ya göre ise, yeni gelen kişinin yeni kültürün hakiki bir üyesi olarak kabul edildiği düzeyde yeni kültürü öğrendiği zaman asimile olmuş demektir. Diğer bireylerle iletişimden kaçınarak, kültürel devamlılı̆̆ın sağlanmaya çalışıldığı durumda ayrılma (separation) oluşmaktadır (Berry vd., 2006). Üstündağlı (2009)'ya göre bütünleşme (integration) böyle bir durumda opsiyon olarak karsımıza çıkmaktadır. Bütünleşme, bir ölçüye kadar kültürel bütünlüğün korunduğu ama diğer yandan da daha geniş sosyal ağın bütünleyici parçası olmak yönünde katılımda bulunmaya çalışıldığ durumdur.

Kültürlenme stratejisinde tercihler içeriğe ve zamana bağlı olarak çeşitlilik gösterebilir. Bununla ilgili Berry ve Sam (1997), üç önemli noktayı vurgularlar. İlk olarak, kişinin tek bir strateji tercihi olabileceği gibi kişinin bulunduğu yere göre de strateji tercihi çeşitlilik gösterebilir. Kişinin daha özel alanlarda (ev, geniş̧ aile, etnik toplum gibi) tercih ettiği strateji, genel yerlerde (iş yeri, kamusal tüm alanlar vb.) tercih ettiği stratejiden farklı olabilir.

İkinci olarak, kişiler göç ettikleri toplumdaki farklı deneyimleri sonucunda yeni stratejiler keşfederler. Kişiler yaşanan deneyimler sonucu kimi stratejileri daha 
yararlı ve tatmin edici bulabilirler. Kültürlenme stratejilerinin kullanılmasında bir ardışıklık veya düzen bulunmamaktadır. Son olarak, bireyin ya da grubun tercih ettiği kültürlenme stratejisinin baskın grup tarafından kabul edilip edilmemesi kültürlenme süreci açısından önemlidir.

20.yy.' da tüm dünyada, uluslararası ve ulusal göçün hızla artması ile kültürlenme kavramının önem kazandığı görülmüştür. Kültürlenme farklı kültürlerdeki insanların sosyal etkileşimi sonucunda bireylerin yaşadığı sürekli değişimin karmaşık sürecidir ayrıca sosyal etkileşim aracılığı ile bireylerin bilişlerindeki, davranış ve duygularındaki dönüşümdür (Zea vd., 2003).

Baskın grubun belirli bir kültürlenme stratejisi tercihinin olup olmadığ ve kültürlenen grubun tercih ettiği kültürlenme stratejisinin bilinmesi oldukça önemlidir. Her iki grubun tercih ettiği strateji arasında benzerlik ne kadar fazla ise yeni gelen grubun kültürlenme stresinin düşük, uyumunun ise yüksek olması beklenir (Hovey, 2000). Grupların strateji tercih sürecini etkileyen değişkenlerin bilinmesi, baskın grubun iyileştirme faaliyetlerinde politika geliştirmelerine yardımcı olacaktır.

$\mathrm{Bu}$ anlamda kültürlenen birey yeni ortama uyum sağlayarak hayatını sürdürmeye başlar. Kültürlenme sürecinde geçiş her zaman kolay değildir. Bireyler bu süreçte psikolojik sorunlar yaşayabilir. Riskli olabilecek kültürlenme süreci kültürlenme ile ilgili politika, program geliştirme ve bilgilendirme ile yumuşatılabilir (Sam ve Berry, 1995). Kültürlenme sürecinin başarılı olabilmesi için, kültürlenme kavramı ayrıntıları ile incelenmelidir (Pointkowski vd., 2000).

Kültürlenen bireylerin çoğunda, yeni kültürel bağlama uyum önemli bir konudur. $\mathrm{Bu}$ uyum faktörlerin türüne bağlı olarak pek çok farklı biçimde olabilir. Bazen başat kültür ile kültürlenen birey arasında uyum yüksektir (örn: asimilasyon veya bütünleşme stratejileri). Bazen ise uyum yüksek olmaz (örn: ayrılma ve marjinalleşme stratejileri) (Berry ve Sam, 1997). Bu durumda kültürlenme stresi veya patoloji ortaya çıkar (Romero ve Roberts, 2003). Kültürlenme stratejisi açısından kişilerin uyum düzeyi yüksek stratejileri (asimilasyon ve bütünleşme stratejileri) tercih ettikleri söylenebilir.

Kültürlerarası etkileşimin ulusları ve insanları bir araya getirmesinin yanında dünya toplumuna hizmet edecek eğitim sistemine de yardım etmesi açısından önemi büyüktür. Farklı kültürlerden bireylerin aynı kültür ortamında ve aynı eğitim sisteminde bir arada öğrenim gördükleri gerçeğini göz önünde bulundurarak konunun eğitimle ilişkisine aşağıda yer verilmiştir.

Mümtaz Turhan'a göre eğitim, bütün bir kültürün muhtevasını bir nesilden diğerine aktaran bir süreçtir. Genç nesiller toplumun düzenine, örf ve adetlerine bu sistem sayesinde alıştırılmakta ve onun ideallerine, değerlerine, görüş ve zihniyetine göre yetiştirilmektedir. Böylece kültür, kesintisiz, aralıksız bir şekilde nesilden nesile geçmekte, devamlı bir şekilde akıp gitmektedir (Turhan, 1980). 
Eğitim, yıllar boyunca gelişmişlik derecesi ne olursa olsun her toplumda ve devlette en önemli sorunlardan olmuş, devletlerin politikalarında eğitimin az ya da çok yeri bulunmuştur. Yine hangi toplumda bulunursa bulunsun, insanlar elverişli şartları buldukları zaman öğretim ve eğitime ilgi duymuştur. Bunun okullarda geçen on iki, on beş yıllık dönemi, ortalama insan ömrünün 70 sene kabul edilmesi durumunda tüm hayatının yaklaşık 1/6'sına tekabül ettiğini görürüz.

Eğitim ve öğretim, çağlar boyunca toplumların gelişme ve ilerleme yolundaki en büyük lokomotifi olmuştur ve halen de öyledir. Günümüzde de bu özelliğini sürdüren eğitim ve öğretim öncelikle ailede başlar ve daha sonra da okullarda devam eder. Burada bizim ele aldığımız ve alacağımız, bu okulların genelde son adımı sayılan yükseköğretim kurumlarıdır.

Özellikle 2. Dünya savaşı sonrası gelişen toplum yapıları ve siyası ortamlar, birçok ülkede yükseköğrenim kurumlarına verilen önemi arttırmıştır. Zamanla -özellikle az gelişmiş ve gelişmekte olan ülkelerde- yükseköğrenim kurumlarının yetersiz olması ve ihtiyacı karşılamaması ve olumsuz siyası ortamlar vb. nedenlerle öğrenim görmek isteyen birçok öğrencinin daha gelişmiş ülkelere yükseköğretim yapmak için gitmeleri sonucunu doğurmuştur.

Eğitim sistemleri incelendiğinde her toplumda ve her kültürde eğitimin yaşamsal ve fonksiyonel olması esas alınmıştır. Yaşamsal ve fonksiyonel olması, o kültür içinde yetişmiş bireylerin kendi kültürünü tanıması, olgunlaştırıp geliştirmesi, hem kendi ülkesinde hem de başka ülkelerde eğitimi sırasında ve sonrasında insanlık hizmetine sunmasında kültürlerarası etkileşimin tahlil edilmesinin büyük yararları olacaktır.

Kültürleri farklı öğrencilerin öğrenme tercihleri de birbirinden farklı olabilir. Bu nedenle, küreselleșen dünyada farklı kültürlerden gelen öğrencilere eğitim veren okullar, üniversiteler veya çeşitli eğitim kurumları kültürlerarası iletişime destek olabilmeli ve öğrencilerin çoklu bakış kazanabilmelerini sağlamalıdır. İçinde yaşadığımız dönemde, ülkeler arasında bulunan sınırların, bilim ve teknolojideki gelişmeler sayesinde ortadan kalktığını söylemek yanlış olmayacaktır. Farklı kültürlerin bir araya gelmesi ve kültürlerarası diyalogun geliştirilmesi bu dönemde tüm ülkeler için bir zorunluluk haline gelmiştir (Cırık, 2008).

Son yıllarda hem Türkiye'de hem de diğer ülkelerde meydana gelen toplumsal değişiklikler de dikkate alınarak, Türkiye' ye eğitim amaçlı gelen yabancı uyruklu bireylerin kültürlenme düzeylerinin araştırılması gerekmektedir. Zira Türkiye Cumhuriyetine eğitim amacıyla farklı kültürlerden gelen bireylerin kültürlenme düzeyleri bilinmemektedir. Bu bağlamda çalışmada, farklı kültürlerden gelen bireylerin eğitim ortamlarında kültürlenme düzeylerinin incelenmesi ve kültürlenme düzeyini ölçecek bir ölçme aracının geliştirilmesi amaçlanmaktadır. 


\section{YÖNTEM}

\subsection{Araştırma Modeli}

$\mathrm{Bu}$ araştırma, kültürlenmenin çeşitli değişkenler açısından ele alındığı tarama modelinde bir araştırmadır. Tarama modelleri, geçmişte ya da halen var olan bir durumu var olduğu şekliyle betimlemeyi amaçlayan araştırma yaklaşımlarıdır (Karasar, 2004). Bu araştırmada veriler, yurtdışından Türkiye'ye gelmiş ve öğrenimlerine farklı üniversitelerde devam eden farklı yaşlardaki bireylerden elde edilmiştir.

\section{2. Çalışma Grubu}

$\mathrm{Bu}$ çalışma için 350 katılımcıya veri toplama araçları uygulanmış, bu uygulamada elde edilen veriler kontrolden geçirilmiştir. Verilere ilişkin ilk inceleme sonuçlarına göre, ölçeklerdeki maddelerin $\% 5$ veya daha fazlasını boş bırakan ya da cevaplarında açıkça merkeze kayma eğilimi gözlenen toplam 40 kişi araştırma grubundan çıkarılmıştır. Kalan 310 kişi üzerinde yapılan uç değer analizleri sonucunda da 10 gözlem analiz dışı bırakılmış, böylece geriye kalan toplam 300 katılımcıdan elde edilen verilerle analizler gerçekleştirilmiştir.

$\mathrm{Bu}$ çalışma grubunda yer alabilmek için belirlenen ölçüt de "Ankara' daki herhangi bir üniversitede eğitim alıyor olmak" şeklinde tanımlanmıştır.

Tablo 2. Kültürlenme Grubunun Çeşitli Değişkenlere Göre Dağılımı

\begin{tabular}{|c|c|c|c|}
\hline Değişken & Düzey & $\mathrm{N}$ & $\%$ \\
\hline \multirow{2}{*}{ Cinsiyet } & Kadın & 88 & 29.3 \\
\hline & Erkek & 212 & 70.7 \\
\hline \multirow{2}{*}{ Türkiye'de Oturduğu Yer } & Ev & 228 & 76.0 \\
\hline & Yurt & 72 & 24.0 \\
\hline \multirow{3}{*}{ Medeni Durum } & 1. Evli & 17 & 5.7 \\
\hline & 2. Bekar & 277 & 92.3 \\
\hline & 3. Dul & 6 & 2.0 \\
\hline \multirow{3}{*}{ Yaş } & 1. $17-25$ yaş & 204 & 68.0 \\
\hline & 2. $26-33$ yaş & 89 & 29.7 \\
\hline & 3. $34-45$ yaş & 7 & 2.3 \\
\hline \multirow{4}{*}{ Türkiye'de Kalış Süresi } & $1.05-10 \mathrm{y} 1 \mathrm{l}$ & 184 & 61.3 \\
\hline & 2. $11-15$ y1l & 82 & 27.3 \\
\hline & 3. $16-20$ y1l & 24 & 8.0 \\
\hline & 4. $21-25 \mathrm{y} 1 \mathrm{l}$ & 10 & 3.3 \\
\hline \multirow{3}{*}{ Gelinen Ülke / Bölge } & 1. Kafkasya & 186 & 62.0 \\
\hline & 2. Avrupa & 51 & 17.0 \\
\hline & 3. Ortadoğu & 63 & 21.0 \\
\hline \multirow{3}{*}{ Yerleşim Birimi } & 1. Köy & 21 & 7.0 \\
\hline & 2. Kasaba & 23 & 7.7 \\
\hline & 3. Şehir & 256 & 85.3 \\
\hline
\end{tabular}




\begin{tabular}{llcc}
\hline & 1. Dil & 17 & 5.7 \\
& 2. Sağlık & 81 & 27.0 \\
Öğrenim Gördükleri Alan & 3. Sosyal & 168 & 56.0 \\
& 4. Fen & 9 & 3.0 \\
& 5. Mühendislik & 25 & 8.3 \\
\hline \multirow{4}{*}{ Birlikte İkamet Ettiği kişi } & 1. Kendi vatandaş1 & 120 & 40.0 \\
& 2. T.C vatandaş1 & 67 & 22.3 \\
& 3. Yalnız & 27 & 9.0 \\
& 4. Diğer & 86 & 28.7 \\
\hline
\end{tabular}

Tablo 2'de sunulan değişkenler incelendiğinde cinsiyete göre dağılımda erkeklerin sayısının ( $N=212, \% 70.7)$ yüksek olduğu, Türkiye'de oturdukları yere göre dağılımda yurtta oturanların sayısının $(\mathrm{N}=72, \% 24.0)$ az olduğu gözlenmektedir. Medeni duruma göre dağılımda ise bekârların sayısının $(\mathrm{N}=277, \% 92.3)$ yüksek olduğu, yaşa göre dağılımda 17-25 yaş aralığındaki bireylerin sayısının $(\mathrm{N}=204$, \%68.0) yüksek olduğu görülmektedir. Türkiye'de kalış süresine göre dağılıma bakıldığında 05-10 yıl kalanların sayısının $(\mathrm{N}=184, \% 61.3)$ yüksek olduğu, gelinen bölgeye göre dağılımda ise Kafkasya'dan gelenlerin sayısının ( $N=186$, \%62.0) yüksek olduğu anlaşılmaktadır. Ülkelerindeki yerleşim birimine göre dağılımda ise köyde oturanların sayısının $(\mathrm{N}=21, \%$ 7.0) az olduğu gözlenmektedir. Öğrenim gördükleri alana göre dağılım incelendiğinde, sosyal alanında öğrenim görenlerin sayısının ( $\mathrm{N}=168, \% 56.0)$ yüksek olduğu, Türkiye'de birlikte ikamet ettiği kişiye göre dağılımda ise kendi vatandaşlarıyla oturan sayısının $(\mathrm{N}=80$, \%41.7) yüksek olduğu görülmektedir.

\subsection{Veri Toplama Arac1}

Bu araştırmada veriler "Kişisel Bilgi Formu" ve araştırmacı tarafından geliştirilen "Kültürlenme Ölçeği”" (Acculturation Scale) kullanılmıştır. Ölçeklerle ilgili bilgiler detaylı bir şekilde aşağıda verilmiştir.

\subsection{Kişisel Bilgi Formu}

Katılımcıların cinsiyet, medeni durum, yaş, Türkiye'deki ikamet süresi, geldiği ülke, ülkesinde ikamet ettiği yerleşim birimi, öğrenim gördüğü alan, Türkiye'de nerede oturduğu ve Türkiye'de kiminle yaşadığı gibi demografik özelliklerine ilişkin bilgileri toplamak amacıyla hazırlanmıştır. Kişisel Bilgi Formu, diğer ölçme aracıyla birlikte kullanılmıştır.

\subsection{Kültürlenme Ölçeği}

Kültürlenme ölçeği, araştırmacı tarafindan bu araştırmada kullanılmak üzere geliştirilmiştir. Ölçek geliştirme sürecinde, öncelikle kültürlenme ile ilgili kuramsal açıklamalarda sıklıkla vurgulanan boyutlar belirlenmiştir. Belirlenen boyutlar şunlardır: asimilasyon, ayrılma ve bütünleşme. Bu üç boyutu içerecek 
şekilde, öncelikle bir madde havuzu oluşturulmuştur. Daha sonra bu maddeler 7 uzmanın görüşüne sunulmuş, uzmanlardan alınan geribildirimler doğrultusunda gerekli düzeltmeler yapılarak ölçeğe son şekli verilmiştir.

Kültürlenme farklı şekillerde ve farklı yöntemlerle ölçülebilir. Bu araştırmada, kültürlenme düzeyi, araştırmacı tarafından geliştirilen ölçme aracının içerdiği boyutlarla ölçülmüş̧ür. Ölçekte bütünleşme stratejisi 31 , ayrılma stratejisi 24 , asimilasyon stratejisi 29 madde ile ölçülmektedir. Ölçek rastgele sıralanmış toplam 84 maddeden oluşmaktadır ve her bir madde 5'li Likert tarzında düzenlenmiştir. Katılımcıların kendilerini her bir madde için 5 "Tamamen katılıyorum" ve 1 "Hiç katılmıyorum" aralığında değerlendirmeleri istenmiştir.

Ölçekte her bir stratejinin ortalaması, bireysel olarak tercih edilen kültürlenme stratejisini ortaya koymaktadır. Bir alt ölçekten yüksek puan almak, bireyin en çok o stratejiyi kullanma eğilimini ifade etmektedir.

\section{6. Ölçeğin Güvenirliği}

Ölçeğin güvenirliği için iç tutarlılık katsayısı (alfa) hesaplanmıştır. Yapılan analiz sonucunda ölçeğin iç tutarlılık katsayısı 0.82 olarak bulunmuştur. Bu değer yüksek düzeyde bir iç tutarlılığa işaret etmektedir.

Yapılan faktör analizi ve güvenirlik analizi sonuçları kültürlenme ölçeğinin geçerli ve güvenilir bir ölçme aracı olduğunu ve Türk kültüründe kullanılabileceğini göstermiştir.

\section{7. Ölçeğin Geçerliği}

\subsubsection{Dil Geçerliliği}

Türkçe Formu: Kültürlenme Ölçeği'nin geliştirilmesi aşamasında, öncelikle madde havuzu oluşturulmuştur. Ardından ölçek Türk dili kurallarına hakim akademisyenler ve Türkçe öğretmenleri tarafindan kontrol edilmiştir. Elde edilen Türkçe formu yine alanda akademik çalışmaları bulunan 10 uzman tarafindan dil açısından değerlendirilmiş ve uyarılar doğrultusunda ölçeğe son hali verilmiştir. Yine uzman görüsü doğrultusunda ölçek "Kültürlenme Ölçeği" olarak adlandırılmıştır.

İngilizce Formu: Kültürlenme ölçeğinin dil geçerliliği için geri çeviri (back translation) yöntemi kullanılmıştır (Karasar, 1995). Ölçek, İngilizceye hakim, yurt dışında yaşamış, ve birisi mütercim olmak üzere dört uzman ve bir öğretim üyesi tarafindan İngilizceye çevrilmiş, çeviriler karşılaştırılarak tek bir form haline getirilmiştir. Sonra İngilizce maddeler, ölçeğin aslını görmemiş farklı bir dil uzmanı tarafından Türkçeye çevrilmiştir. Geri çeviri anlatımları, özgün anlatımlarla karşılaştırılmıştır. Çevirisi tamamlanan ölçek için alanda uzman öğretim 5 öğretim üyesinin görüsü alınmıştır. Uzmanlara Kültürlenme Ölçeği' nin Ingilizce ve Türkçesi birlikte verilerek, maddelerinin dil ve içerik uygunluğunu 
bakımından değerlendirmeleri istenmiştir. Bazı ifadelerde küçük değişiklik önerileri olmuş ve bu öneriler doğrultusunda yeniden gözden geçirilerek ölçeğe son hali verilmiştir.

\section{Yapı Geçerliği}

$\mathrm{Bu}$ çalışmada ölçeğin yapı geçerliliğini sınamak için açımlayıcı faktör analizi yapılmıştır. Faktör analizi, ölçme aracının yapısını, aynı yapıyı ya da niteliği ölçen değişkenleri bir araya toplayarak ölçmeyi, az sayıda faktör ile açıklamayı amaçlayan bir istatistiksel tekniktir (Büyüköztürk, 2002). Ancak faktör analizi, tüm veri setleri için uygun olmayabilir. Verilerin, faktör analizi için uygunluğu Kaiser-Meyer-Olkin (KMO) katsayısı ile bulunur. Bartlett küresellik testinin aldığı değer ve onun anlamlılığı ise değişkenlerin birbirleri ile ilişki gösterip göstermediklerini test eder. KMO değerinin 0.60'dan yüksek bulunması ve Bartlett testinin anlamlı bulunması verilerin faktör analizi için uygun olduğunu gösterir (Büyüköztürk, 2002). Veriler üzerinde faktörleri belirlemek için Temel Bileşenler Analizi yapılmıştır.

Faktör analizi için ölçek, öğrenim görmek amaciyla Türkiye'nin değişik üniversitelerine gelen 300 yabanc1 uyruklu öğrenciye uygulanmıştır. $\mathrm{Bu}$ öğrenciler, Ankara'daki farklı üniversitelerin farklı bölümlerinde eğitim görmektedir.

Kültürlenme ölçeği için 300 kişi üzerinde yapılan faktör analizinde KMO 0.80 çıkmıştır. Bu durum örneklem büyüklüğünün faktör analizi için uygun olduğunu göstermektedir. Bartlett testi sonucu da anlamlı bulunmuştur [ $\chi^{2}=5676,72$, $\mathrm{P}<.01]$. Bu sonuçlar verinin faktör çıkartmak için uygun olduğunu göstermektedir.

Kültürlenme ölçeğinin açımlayıcı faktör analizinde 15 madde iki faktöre birden yüklenip faktör yapısını bozduğu için analizden çıkartılıp tekrar faktör analizi yapılmıştır. Analiz sonucunda 9 madde hiçbir faktöre yüklenmediği için analizden çıkartılıp tekrar analiz yapılmıştır. Yapılan analiz sonucunda üç faktörlü (ayrılma, asimilasyon, bütünleşme) bir yapı elde edilmiştir.

Kültürlenme ölçeğinin varimaks yöntemi ile döndürülmüş açımlayıcı faktör analizi sonucunda elde edilen üç faktörlü yapı aşağıda detaylı bir şekilde sunulmuştur:

1. Faktörde (Ayrılma) 1, 4, 10, 13, 16, 19, 22, 34, 37, 52, 55, 61, 64, 67, 73, 76, $82,85,88,91,97,100,103,106$ numaralı maddeler yer almaktadır ve toplam varyansın $\% 15$ 'ini açıklamaktadır.

2. Faktörde (Asimilasyon) 5, 11, 14, 17, 20, 23, 26, 29, 32, 35, 38, 41, 44, 47, 50, $53,56,59,62,65,68,74,77,80,86,89,95,98,107$ numaralı maddeler yer almaktadır ve toplam varyansın $\% 10$ 'nu açıklamaktadır.

3. Faktörde (Bütünleşme) 3, 6, 15, 18, 21, 24, 27, 30, 33, 36, 39, 42, 45, 48, 51, $54,60,63,66,69,72,75,78,81,84,87,90,99,102,105,108$ numaralı maddeler yer almaktadır ve toplam varyansın $\% 7$ 'sini açıklamaktadır. 
$\mathrm{Bu}$ analizler sonucu uzman görüşü de alınarak "Kültürlenme Ölçeği’”nin kültürlenme düzeyini ölçme bakımından geçerli bir ölçek olduğuna karar verilmiştir. Ölçeğin bu formu, 84 maddeden ve 3 faktörden oluşmaktadır.

Tablo 3a. Kültürlenme Ölçeği Açımlayıcı Faktör Analizi Sonucu

Faktör 1 Döndürülmüş Faktör Yük Değeri Madde-Toplam Korelasyonu

\begin{tabular}{|c|c|c|}
\hline 68 & .632 & .816 \\
\hline 80 & .631 & .816 \\
\hline 62 & .604 & .818 \\
\hline 74 & .602 & .818 \\
\hline 29 & .598 & .817 \\
\hline 26 & .597 & .818 \\
\hline 44 & .590 & .817 \\
\hline 77 & .590 & .816 \\
\hline 20 & .585 & .816 \\
\hline 56 & .577 & .818 \\
\hline 14 & .575 & .817 \\
\hline 59 & .574 & .819 \\
\hline 38 & .566 & .816 \\
\hline 50 & .560 & .817 \\
\hline 23 & .558 & .814 \\
\hline 47 & .551 & .818 \\
\hline 41 & .547 & .818 \\
\hline 17 & .539 & .818 \\
\hline 32 & .533 & .819 \\
\hline 65 & .517 & .814 \\
\hline 11 & .511 & .820 \\
\hline 5 & .507 & .819 \\
\hline 35 & .474 & .819 \\
\hline 98 & .473 & .819 \\
\hline 95 & .419 & .819 \\
\hline 53 & .409 & .816 \\
\hline 107 & .396 & .818 \\
\hline 86 & .374 & .819 \\
\hline 89 & .320 & .819 \\
\hline \multicolumn{3}{|c|}{ Açıklanan Varyans: \%15.09 } \\
\hline \multicolumn{3}{|c|}{ Özdeğer: 12.68} \\
\hline
\end{tabular}

Tablo 3b. Kültürlenme Ölçeği Açımlayıcı Faktör Analizi Sonucu

Faktör 2 Döndürülmüş Faktör Yük Değeri Madde-Toplam Korelasyonu

\begin{tabular}{cll}
\hline 24 & .668 & .820 \\
108 & .648 & .818 \\
30 & .642 & .821 \\
60 & .635 & .819
\end{tabular}




\begin{tabular}{ccc}
42 & .616 & .821 \\
66 & .610 & .820 \\
33 & .602 & .821 \\
48 & .596 & .821 \\
21 & .556 & .820 \\
54 & .552 & .820 \\
78 & .534 & .822 \\
84 & .526 & .819 \\
27 & .524 & .823 \\
63 & .521 & .819 \\
6 & .517 & .821 \\
105 & .513 & .818 \\
72 & .504 & .820 \\
75 & .504 & .820 \\
45 & .483 & .819 \\
15 & .469 & .822 \\
39 & .468 & .822 \\
69 & .452 & .821 \\
87 & .420 & .821 \\
81 & .397 & .821 \\
51 & .384 & .822 \\
36 & .370 & .820 \\
90 & .364 & .817 \\
99 & .361 & .821 \\
102 & .356 & .819 \\
18 & .349 & .822 \\
3 & .339 & .822 \\
\hline Aç1klanan Varyans: \%11.55 & \\
Özdeğer: 8.55 & & \\
& & \\
\hline & & \\
\hline & &
\end{tabular}

Tablo 3c. Kültürlenme Ölçeği Açımlayıcı Faktör Analizi Sonucu

Faktör 3 Döndürülmüş Faktör Yük Değeri Madde-Toplam Korelasyonu

\begin{tabular}{cll}
\hline 67 & .731 & .817 \\
52 & .672 & .817 \\
55 & .668 & .818 \\
34 & .648 & .818 \\
73 & .643 & .817 \\
76 & .642 & .816 \\
61 & .591 & .822 \\
106 & .581 & .818 \\
22 & .562 & .816 \\
64 & .547 & .815 \\
88 & .527 & .819 \\
37 & .515 & .817 \\
19 & .511 & .819 \\
103 & .501 & .819
\end{tabular}




\begin{tabular}{ccc} 
s13 & .429 & .819 \\
82 & .425 & .820 \\
10 & .419 & .821 \\
97 & .384 & .819 \\
1 & .358 & .822 \\
100 & .353 & .820 \\
4 & .343 & .823 \\
16 & .337 & .819 \\
85 & .325 & .819 \\
91 & .309 & .820 \\
\hline Açıllanan Varyans: \%6.79 \\
Özdeğer: 5.70 \\
\hline Tüm Ölçek için Cronbach-Alpha: 82 \\
KMO: 0.80 \\
Barlett Küresellik Testi $\left[\chi^{2}=5676.72\right.$, P $\left.<.01\right]$ \\
\hline
\end{tabular}

$\mathrm{Bu}$ analiz sonucunda, 3 faktör altında toplanan ve toplam 84 maddeden oluşan Kültürlenme Ölçeği'nin, bu araştırmada veri toplama araci olarak kullanılabileceğine karar verilmiştir. Ölçekten alınabilecek toplam puan 84 ile 420 arasında değişebilmektedir.

\subsection{Verilerin Analizi}

Kültürlenmenin çeşitli değişsenlere göre karşılaştırılmasında t-testi (Cinsiyet, medeni durum, Türkiye'de kalış süresi, gelinen ülke/bölge ve Türkiye'de oturduğu yer) ve tek yönlü ANOVA (Yaş, yerleşim birimi ve Türkiye'de birlikte ikamet ettiği kişi) istatistiğgi kullanılmıştır. Kültürlerarası etkileşim algısının yordayıcıları olan araştırma değişkenleriyle (Cinsiyet, medeni durum, Türkiye'de kalış süresi, gelinen ülke/bölge ve Türkiye'de oturduğu yer, yaş, yerleşim birimi ve Türkiye'de birlikte ikamet ettiği kişi) ilişkisinin belirlenmesi için çoklu regresyon analizi yapılmıştır.

Kültürlenmeyi ölçmek amacıyla geliştirilen ölçeğin yapı geçerliğini incelemek için faktör analizi kullanılmıştır. Faktör analizi, aynı yapıyı ya da niteliği ölçen değişkenleri bir araya toplayarak ölçmeyi az sayıda faktör ile açıklamayı amaçlayan bir istatistiksel tekniktir. Faktör analizi bir faktörleşme ya da ortak faktör adı verilen yeni kavramları (değişkenleri) ortaya çıkarma ya da maddelerin faktör yük değerlerini kullanarak kavramların işlevsel tanımlarını elde etme süreci olarak da tanımlanmaktadır (Büyüköztürk, 2002).

\section{BULGULAR}

4.1. Kültürlenmenin Asimilasyon Alt Boyutu İle Demografik Değişkenlerin İlişkileri 
Katılımcıların, kültürlenmenin asimilasyon alt boyutundan aldıkları toplam puanların, cinsiyet, medeni durum, yaş, Türkiye'deki ikamet süresi, geldiği ülke, ülkesinde ikamet ettiği yerleşim birimi, öğrenim gördüğü alan, Türkiye'de nerde oturduğu ve Türkiye'de beraber ikamet ettikleri kişi değişkenlerine göre farklılaşıp farklılaşmadığına bakılmıştır.

Tablo 4. Asimilasyon Puanlarının Cinsiyet ve Türkiye'de Oturduğu Yer Değişkenine Göre Karşılaştırılması

\begin{tabular}{|c|c|c|c|c|c|c|}
\hline Değişken & Düzey & $\mathrm{N}$ & $\overline{\mathrm{X}}$ & $\mathrm{S}$ & sd & $\mathrm{t}$ \\
\hline \multirow{2}{*}{ Cinsiyet } & Kadın & 88 & 62.85 & 15.85 & \multirow{2}{*}{298} & \multirow{2}{*}{1,61} \\
\hline & Erkek & 212 & 66.35 & 17.62 & & \\
\hline \multirow{2}{*}{ Türkiye'de Oturduğu Yer } & $\mathrm{Ev}$ & 228 & 64.73 & 17.13 & \multirow{2}{*}{298} & \multirow{2}{*}{1,083} \\
\hline & Yurt & 72 & 67.24 & 17.25 & & \\
\hline
\end{tabular}

* $\mathrm{P}<.05$

Tablo 4'de sunulan Asimilasyon puanlarının çeşitli değişkenlere göre karşılaştırılmasına ilişkin bağımsız $t$ testi sonuçları incelendiğinde, asimilasyonun cinsiyet ve Türkiye'de oturulan yer değişkenine göre farklılık göstermediği görülmektedir.

Tablo 5. Asimilasyon Puanlarının Çeşitli Değişkenlere Göre Karşılaştırılması

\begin{tabular}{|c|c|c|c|c|c|c|c|}
\hline Değişken & Düzey & $\mathrm{N}$ & $\bar{X}$ & S & sd & $\mathrm{F}$ & $\begin{array}{c}\text { Anlaml1 } \\
\text { fark } \\
\text { (Scheffe } \\
\text { testi) } \\
\end{array}$ \\
\hline \multirow{3}{*}{$\begin{array}{l}\text { Medeni } \\
\text { Durum }\end{array}$} & 1. Evli & 17 & 55.76 & 10.87 & \multirow{3}{*}{2,297} & \multirow{3}{*}{$3.14 *$} & \multirow{3}{*}{$1-2$} \\
\hline & 2. Bekar & 277 & 66.01 & 17.45 & & & \\
\hline & 3. Dul & 6 & 60.50 & 6.31 & & & \\
\hline \multirow{3}{*}{ Yaş } & 1. $17-25$ yaş & 204 & 66.58 & 17.88 & \multirow{3}{*}{2,297} & \multirow{3}{*}{1.83} & \multirow{3}{*}{-} \\
\hline & 2. $26-33$ yaş & 89 & 62.88 & 15.77 & & & \\
\hline & 3. $34-45$ yaş & 7 & 59.71 & 4.95 & & & \\
\hline \multirow{4}{*}{$\begin{array}{l}\text { Türkiye'de } \\
\text { Kalış Süresi }\end{array}$} & 1. 05-10 y1l & 184 & 67.79 & 17.06 & \multirow{4}{*}{3,296} & \multirow{4}{*}{$4.77 *$} & \multirow{4}{*}{$1-2$} \\
\hline & 2. $11-15 \mathrm{y} 1 \mathrm{l}$ & 82 & 62.24 & 15.53 & & & \\
\hline & 3. $16-20 \mathrm{y} 1 \mathrm{l}$ & 24 & 55.95 & 13.97 & & & \\
\hline & 4. $21-25 \mathrm{y} 1 \mathrm{l}$ & 10 & 67.60 & 27.25 & & & \\
\hline \multirow{3}{*}{$\begin{array}{l}\text { Gelinen Ülke } \\
\text { / Bölge }\end{array}$} & 1. Kafkasya & 186 & 62.01 & 15.25 & \multirow{3}{*}{2,297} & \multirow{3}{*}{$9.66^{*}$} & \multirow{3}{*}{$\begin{array}{l}1-2 \\
2-3\end{array}$} \\
\hline & 2. Avrupa & 51 & 71.17 & 22.15 & & & \\
\hline & 3. Ortadoğu & 63 & 70.36 & 15.60 & & & \\
\hline \multirow{3}{*}{$\begin{array}{l}\text { Yerleşim } \\
\text { Birimi }\end{array}$} & 1. Köy & 21 & 68.66 & 21.04 & \multirow{3}{*}{2,297} & \multirow{3}{*}{.44} & \multirow{3}{*}{-} \\
\hline & 2. Kasaba & 23 & 65.78 & 14.53 & & & \\
\hline & 3. Şehir & 256 & 65.01 & 17.06 & & & \\
\hline \multirow{6}{*}{$\begin{array}{l}\text { Öğrenim } \\
\text { Gördükleri } \\
\text { Alan }\end{array}$} & 1. Dil & 17 & 62.52 & 15.31 & \multirow{5}{*}{4,295} & \multirow{5}{*}{$6.14 *$} & \multirow{5}{*}{$\begin{array}{l}1-5 \\
2-5 \\
3-5\end{array}$} \\
\hline & 2. Sağlık & 81 & 60.97 & 15.02 & & & \\
\hline & 3. Sosyal & 168 & 65.27 & 18.15 & & & \\
\hline & 4. Fen & 9 & 73.44 & 14.85 & & & \\
\hline & 5. Mühendislik & 25 & 78.76 & 10.48 & & & \\
\hline & 1. Kendi vatandaş 1 & 120 & 64.80 & 14.94 & 3,296 & 2.17 & - \\
\hline
\end{tabular}




\begin{tabular}{lllll} 
Birlikte & 2. T.C vatandaşı & 67 & 69.80 & 17.75 \\
İkamet Ettiği & 3. Yalnız & 27 & 64.03 & 23.21 \\
kişi & 4. Diğer & 86 & 62.97 & 17.06 \\
\hline
\end{tabular}

$* \mathrm{P}<.05$

Tablo 5'de sunulan Asimilasyon puanlarının çeşitli değişkenlere göre karşılaştırılmasına ilişkin tek yönlü ANOVA sonuçları incelendiğinde medeni durum $[\mathrm{F}(2.297)=3.14 ; \mathrm{p}<.05]$, Türkiye'de kalış süresi $[\mathrm{F}(3.296)=4.77 ; \mathrm{p}<.05]$, gelinen ülke/bölge $[\mathrm{F}(2.297)=9.66 ; \mathrm{p}<.05]$, ve öğrenim gördükleri alan $[\mathrm{F}(4.295)=6.14 ; \mathrm{p}<.05]$ değişkenlerine göre anlamlı fark olduğu görülmektedir. Farkın kaynağını bulmak üzere uygulanan Scheffe Testi sonuçları incelendiğinde, medeni duruma göre 1.evli ve 2.bekar olanlar; Türkiye'de kalış süresine göre 1.510 yıl ve 2.11-15 yıldır Türkiye'de olanlar; gelinen ülke/bölgeye göre 1.Kafkasya ve 2.Avrupa; 2.Avrupa ve 3.Ortadoğu; öğrenim gördükleri alan göre ise 1.Dil ve 5.Mühendislik; 2.Sağlık ve 5.Mühendislik; 3.Sosyal ve 5.Mühendislik farklarının anlamlı olduğu belirlenmiştir. Diğer değişkenine göre ise anlamlı fark yoktur.

Tablo 5'de görüldüğü gibi bekar olmak asimilasyon puanlarını artırmaktadır. Bekar katılımcıların evli katılımcılara göre ailesinin ve çocuklarının olmaması, evli katılımcılara göre daha bağımsız olmaları asimilasyon riskini artırdığ söylenebilir. Benzer bir şekilde, Şeker (2006)'in yaptı̆̆ 1 araştırmada da evli ve bekar katılımcıların asimilasyon alt boyutundan aldıkları toplam puan ortalamaları arasında anlamlı bir fark olduğu bulunmuştur. Araştırma sonucunda bekar katılımcıların daha fazla asimile oldukları gözlemlenmiştir.

Tablo 5'de Türkiye'de kalış süresi değişkenine bakıldığında, Türkiye'de daha az zaman geçirmiş olmak asimilasyon puanlarını artırmaktadır. Asimilasyonun zamanla doğru orantılı olduğu varsayılırken, bu araştırmada tam tersi bulgular elde edilmiştir. Bektaş vd. (2006) araştırmalarında yabancı öğrencilerin kültürlenme tutumu olarak daha çok asimilasyona yakın oldukları ama aynı zamanda kendi kültürel kimliklerinden de vazgeçmediklerini belirtmişılerdir. Bunun açıklaması olarak da yabancı bir kültürde uyum sağlamaları gerektiğine inandıklarını ve bunu normal algıladıklarını belirtmişlerdir.

Tablo 5'de gelinen ülke değişkenine bakıldığında, Avrupa'dan gelen katılımcıların asimilasyon puanlarının yüksek olduğu görülmektedir. Avrupa'dan gelen katılımcıların azınlıkta olması ve diğer ülkelerden gelen katılımcılara göre vatandaşlarıyla daha az zaman geçirmiş olması ve mecburen Türk arkadaşlarla iletişime girmesi ve o yaşam tarzına en kısa sürede ayak uydurmaya çalışması asimile olmalarına neden olduğu söylenebilir. Özhan (2006)' ’n yaptığı araştırma da bu bulguyu desteklemektedir. Bu araştırmaya göre, asimilasyonda sadece çoğunluk grubun değerlerine doğru bir değişme vardır. Kültürlenmede değişme iki yönlüdür ve değişme çoğunluk ya da azınlık gruplarından birine doğru olabilir.

Tablo 5'de öğrenim gördükleri alan değişkenine bakıldığında, mühendislik alanında öğrenim görenlerin asimilasyon puanlarının yüksek olduğu görülmektedir. Mühendislik alanında okuyan katılımcıların aile bağlarının zayıf 
olması veya kendi ülke vatandaşlarıyla ilişkilerinin iyi olamaması gibi nedenlerden dolayı, mecburen bulundukları kültürü koşulsuz kabul etmeye sebep olmuştur denebilir. Toyokawa ve Toyokawa (2002)'ya göre uluslararası öğrenciler, yabancı bir ülkede kültürlenme sürecinde pek çok problemle karşılaşmaktadırlar. Öğrencilerin en çok okul stresi, özerklik ihtiyacı, ekonomik bağımsızlık, kimlik karmaşası, dil problemi, kültürel sok, yabancı sosyal normlara ve değerlere alışma, eğitim sistemindeki farklılıklar, yalnızlık, ev özlemi, sosyal bağların kopması gibi sorunları yasadıklarını belirtmişılerdir.

\subsection{Kültürlenmenin Ayrılma Alt Boyutu İle Demografik Değişkenlerin İlişkileri}

Katılımcıların kültürlenmenin ayrılma alt boyutundan aldıkları toplam puanların, cinsiyet, medeni durum, yaş, Türkiye'deki ikamet süresi, geldiği ülke, ülkesinde ikamet ettiği yerleşim birimi, öğrenim gördüğü alan, Türkiye'de nerde oturduğu ve Türkiye'de beraber ikamet ettikleri kişi değişkenlerine göre farklılaşıp farklılaşmadığına bakılmıştır.

Tablo 6. Ayrılma Puanlarının Cinsiyet ve Türkiye'de Oturduğu Yer Değişkenine Göre Karşılaştırılması

\begin{tabular}{|c|c|c|c|c|c|c|}
\hline Değişken & Düzey & $\mathrm{N}$ & $\overline{\mathrm{X}}$ & $\mathrm{S}$ & $\mathrm{sd}$ & $\mathrm{t}$ \\
\hline \multirow{2}{*}{ Cinsiyet } & Kadın & 88 & 76.38 & 17.42 & \multirow{2}{*}{298} & \multirow{2}{*}{0.72} \\
\hline & Erkek & 212 & 74.74 & 18.16 & & \\
\hline \multirow{2}{*}{ Türkiye'de Oturduğu Yer } & Ev & 228 & 74.23 & 17.74 & \multirow{2}{*}{298} & \multirow{2}{*}{1.72} \\
\hline & Yurt & 72 & 78.39 & 18.34 & & \\
\hline
\end{tabular}

Tablo 6'de sunulan Ayrılma puanlarının çeşitli değişkenlere göre karşılaştırılmasına ilişsin bağımsız $\mathrm{t}$ testi sonuçları incelendiğinde, ayrılmanın cinsiyet ve Türkiye'de oturulan yer değişkenine göre farklılık göstermediği görülmektedir.

Araştırma sonucunda, ayrılma puanlarının cinsiyete göre farklılaşmadığ bulunmuştur $\left[\mathrm{t}_{(298)}=.72 ; \mathrm{p}>.05\right]$. Bu bulgu, ayrılmanın cinsiyet değişkeninden etkilenmediği şeklinde yorumlanabilir. Ama Şeker (2006)' in yaptığı araştırmada, kadınların ve erkeklerin ayrılma alt boyutundan aldıkları toplam puan ortalamaları arasında anlamlı bir farklılık bulunmuştur. Araştırma sonucunda ayrılma stratejisini kadınların daha fazla tercih ettiği saptanmıştır.

Tablo 7. Ayrılma Puanlarının Çeşitli Değişkenlere Göre Karşılaştırılması

\begin{tabular}{llccccccc}
\hline Değişken & \multicolumn{1}{c}{ Düzey } & $\mathrm{N}$ & $\overline{\mathrm{X}}$ & $\mathrm{S}$ & $\mathrm{sd}$ & $\mathrm{F}$ & $\begin{array}{c}\text { Anlaml } \\
\text { fark } \\
\text { (Scheffe } \\
\text { testi) }\end{array}$ \\
\hline Medeni & 1. Evli & 17 & 63.70 & 15.68 & & 2,29 & $4.43 *$ & $1-2$ \\
Durum & 2. Bekar & 277 & 76.09 & 17.92 & &
\end{tabular}




\begin{tabular}{|c|c|c|c|c|c|c|c|}
\hline & 3. Dul & 6 & 67.83 & 12.38 & & & \\
\hline \multirow{3}{*}{ Yaş } & $1.17-25$ yaş & 204 & 77.48 & 17.68 & \multirow{3}{*}{2,29} & \multirow{3}{*}{$5.48 *$} & \multirow{3}{*}{$1-2$} \\
\hline & 2. 26-33 yaş & 89 & 70.80 & 17.79 & & & \\
\hline & 3. $34-45$ yaş & 7 & 65.57 & 15.49 & & & \\
\hline \multirow{4}{*}{$\begin{array}{l}\text { Türkiye' } \\
\text { de Kalış } \\
\text { Süresi }\end{array}$} & $1.05-10 \mathrm{y} 1 \mathrm{l}$ & 184 & 79.65 & 17.09 & \multirow{4}{*}{3,29} & \multirow{4}{*}{$12.0 *$} & \multirow{4}{*}{$\begin{array}{l}1-2 \\
1-3\end{array}$} \\
\hline & 2. $11-15$ y1l & 82 & 70.12 & 17.43 & & & \\
\hline & 3. $16-20 \mathrm{y} 1 \mathrm{l}$ & 24 & 62.66 & 16.37 & & & \\
\hline & 4. 21-25 y1l & 10 & 65.70 & 12.82 & & & \\
\hline Gelinen & 1. Kafkasya & 186 & 75.18 & 18.30 & \multirow{3}{*}{2,29} & \multirow{3}{*}{1.92} & \multirow{3}{*}{-} \\
\hline Ülke / & 2. Avrupa & 51 & 71.62 & 16.71 & & & \\
\hline Bölge & 3. Ortadoğu & 63 & 78.23 & 17.52 & & & \\
\hline \multirow{3}{*}{$\begin{array}{l}\text { Yerleşim } \\
\text { Birimi }\end{array}$} & 1. Köy & 21 & 64.95 & 14.57 & \multirow{3}{*}{2,29} & \multirow{3}{*}{$3.77 *$} & \multirow{3}{*}{$1-3$} \\
\hline & 2. Kasaba & 23 & 76.39 & 16.87 & & & \\
\hline & 3. Şehir & 256 & 75.96 & 18.07 & & & \\
\hline \multirow{5}{*}{$\begin{array}{l}\text { Öğrenim } \\
\text { Gördükl } \\
\text { eri Alan }\end{array}$} & 1. Dil & 17 & 73.52 & 16.13 & \multirow{5}{*}{4,29} & \multirow{5}{*}{0.14} & \multirow{5}{*}{-} \\
\hline & 2. Sağlik & 81 & 76.07 & 18.44 & & & \\
\hline & 3. Sosyal & 168 & 75.29 & 18.95 & & & \\
\hline & 4. Fen & 9 & 73.33 & 9.77 & & & \\
\hline & 5. Mühendislik & 25 & 73.84 & 12.70 & & & \\
\hline Birlikte & 1. Kendi vatandaş1 & 120 & 79.03 & 17.55 & \multirow{4}{*}{3,29} & \multirow{4}{*}{$5.91 *$} & \multirow{4}{*}{$\begin{array}{l}1-2 \\
1-3\end{array}$} \\
\hline İkamet & 2. T.C vatandaş1 & 67 & 70.71 & 12.73 & & & \\
\hline Ettiğgi & 3. Yalnız & 27 & 66.11 & 16.37 & & & \\
\hline kişi & 4. Diğger & 86 & 76.27 & 20.69 & & & \\
\hline
\end{tabular}

*P<.05

Tablo 7'de sunulan ayrılma puanlarının çeşitli değişkenlere göre karşılaştırılmasına ilişkin tek yönlü ANOVA sonuçları incelendiğinde medeni durum $[\mathrm{F}(2.297)=4.43 ; \mathrm{p}<.05]$, yaş $[\mathrm{F}(2.297)=5.48 ; \mathrm{p}<.05]$, Türkiye'de kalış süresi $[\mathrm{F}(3.296)=12.0 ; \mathrm{p}<.05]$, yerleşim birimi $[\mathrm{F}(2.297)=3.77 ; \mathrm{p}<.05]$ ve Türkiye'de birlikte ikamet ettikleri kişi $[\mathrm{F}(3.296)=5.91 ; \mathrm{p}<.05]$ değişkenlerine göre anlamlı fark olduğu görülmektedir. Farkın kaynağını bulmak üzere uygulanan Scheffe Testi sonuçları incelendiğinde, medeni duruma göre 1.evli ve 2.bekar olanlar; yaşa göre 1.17-25 yaş ve 2.26-33 yaş aralığında olanlar; Türkiye'de kalış süresine göre 1.5-10 yıl ve 2.11-15 yıl; $1.5-10$ y1l ve 3.16-20 yıldır Türkiye'de olanlar; yerleşim birimine göre 1.Köy ve 3.Şehirde yaşayanlar; Türkiye'de birlikte ikamet ettikleri kişiye göre 1.Kendi vatandaşları ve 2.T.C vatandaşları; 1.Kendi vatandaşları ve 3.Yalnız yaşayanların farklarının anlamlı olduğu belirlenmiştir. Diğer değişkenine göre ise anlamlı fark yoktur.

Tablo 7'de de görüldüğü gibi bekar olmak ayrılma puanlarını artırmaktadır. Ama Şeker'in (2006) yaptığı araştırmada farklı sonuçlara ulaşılmıştır. Ayrılma alt boyutundan evli katılımciların aldıkları toplam puan ortalamasının, bekar katılımcıların aldıkları toplam puan ortalamasından anlamlı şekilde farklı bulunmuştur. $\mathrm{Bu}$ stratejiyi evli katılımcıların daha fazla tercih ettikleri saptanmıştır.

Tablo 7'de 17-25 yaş grubu katılımcıların ayrılma puanlarının yüksek olduğu görülmektedir. Kültürden etkilenme süreci ve kültürel deneyimlerinin diğer yaş gruplarına göre azlığı ayrılma stratejisini tercih nedenleri olduğu söylenebilir. 
Ayrıca bu yaştaki öğrenci grubu Türkiye'ye yeni geldiği için ailelerini ve ülkelerini özlediklerinden dolayı ayrılmayı tercih ettikleri söylenebilir. Açıkalın vd. (1996) araştırmalarında Türkiye'de yükseköğrenim gören Türk Cumhuriyetleri öğrencilerinin sorunlarını belirlemeyi amaçlamışlardır. Araştırma sonuçlarına göre 17-22 yaş aralığındaki yabancı öğrencilerin en önemli problemler, aile özlemi ve ülke özlemi olarak belirlenmiştir.

Tablo 7'de Türkiye'de kalış süresi değişkenine bakıldığında, Türkiye'de daha az zaman geçirmiş olmanın ayrılma puanlarını artırdığı görülmektedir. Öğrencilerle yapılan görüşme sırasında Türkiye'de kısa süreli kalmayı hedefleyen katılımcıların, Türk kültürünü tanımaya çalışmadıkları, uyum sağlama çabalarının olmadığı gözlenmiştir. Bu gözlem de geri dönme hedefi olan katılımcıların ayrılma puanlarının düşük olma nedeni olduğu şeklinde yorumlanabilir. Araştırma bulguları, alan yazındaki çalışmalarla paralellik göstermektedir. Gün ve Bayraktar'a (2008) göre, geri dönmeyi düşünen biri, göç ettiği toplumu tanımaya, uyum sağlamaya çaba göstermeyecek, ilişkilerini ve hazırlıklarını geri dönmeye yönelik yapacaktır. Göç ettiği toplumun sosyal, kültürel değerlerine mesafeli durabilecek ve öğrenmeye gayret etmeyecektir.

Tablo 7'de ülkesinde yaşadığg yerleşim birimi değişkenine göre, kendi ülkesinde şehirde yaşıyor olmanın ayrılma puanlarını artırdığı görülmektedir. Kendi ülkesinde köyde yaşayan katılımcıların yaşam olanaklarının şehirde yaşayanlara göre daha düşük olduğunu varsayarsak, geldikleri kentte bu olanaklardan daha fazla yararlanacakları için ayrılma puanları düşmektedir. Bunun yanında kendi ülkesinde şehirde yaşayan katılımcıların geldikleri kentte aynı olanakları bulamaması ayrılma puanlarını yükseltmektedir şeklinde yorumlanabilir.

Heterojen bir toplumsal yapı sergileyen kentler, sosyal ve mekânsal çevre içinde bireyler üzerinde farklı etkiler yaratmaktadır. Kentlerde çalışan bireylerin farklı mesleki alanlarda yoğunlaşması, kentsel mekânların kullanımında farklılaşmalar yaratmış; farklı çalışma ve yaşam koşulları içinde farklı alt kültürler ortaya çıkmıştır (Tezcan, 1995). Kentler kırsal kesimden gelen göçmenleri kendi potasında eritip onları Batı kültürünün hâkim olduğu modern kent yaşamına katacak; bireyler, kentin bu ekonomik ve sosyal mekânlarında heterojen ve yoğun ortamda kentli olacaklardır (Tekeli, 1982).

Tablo 7'de bireylerin Türkiye'de birlikte ikamet ettikleri kişi değişkenine bakıldığında, kendi vatandaşlarıyla yaşıyor olmanın ayrılma puanlarını artırdığı görülmektedir. Kendi vatandaşlarıyla yaşıyor olmak, aynı kültürü, aynı dili paylaşıyor anlamı taşıdığı düşünülürse, geldikleri ülkedeki insanlarla daha az iletişime girecekleri ve bunun da ayrılma puanlarını yükselteceği söylenebilir. $\mathrm{Bu}$ bulgu araştırmacının hem kendi hem de çevresindeki yabancı uyruklu kişilerde gözlemlenmiştir. Bireylerin kendi vatandaşlarıyla beraber yaşamayı tercih etmesi Kültürlerarası Duyarlılık Gelişmeli Model'deki Etnosentrik oryantasyonu akla getirmektedir. Gökmen (2005)'e göre etnosentrik oryantasyonda, birey için kendi kültürü temeldir ve var olan diğer kültürler bireyin kültüründen etkilenmektedirler. Dolayısıyla iletişim içinde bulunulan kültürleri kabullenme durumu 
olmamaktadır. Birey dış kültüre tamamen kapalı ve her türlü etkiye karşı savunma konumundadır. Bu durumdaki bireyler farklı kültürlerle iletişim içinde bulunmayı kesinlikle reddetmektedirler. Var olan kültürlerini tek doğru kültür olarak kabul ettikleri için kısıtlı bir dünya görüşüne sahiptirler ve sosyal anlamdaki davranışları da bu yöndedir.

Yabancı öğrencilerin anadillerini günlük ilişki ve iletişimde kullanma tercihi ve sıklığı hiç kuşkusuz iletişimsel ortamların analizinde belirleyici bir ölçüt olarak kabul edilebilir. Türkiye'de yaşayan yabancı öğrencilerin kendi arkadaş iliş̧kilerinde kullandıkları dil tercihinin anadili ağırlıklı olması doğal sayılabilir. Ancak çevre ilişkilerinde kullanılan dilin anadilleri olması, arkadaş seçimindeki önceliğin kendi vatandaşlarından olduğu ve bu tür ilişkilerde Türklerin olmadığı veya sınırlı olduğu şeklindeki bir sonucu doğurmaktadır. Bu görüş, kültürlenme sürecinde yaşanan sorunlara örnek olarak gösterilebilecek değerlerden biri olarak düşünülebilir.

\subsection{Kültürlenmenin Bütünleşme Alt Boyutu İle Demografik Değişkenlerin İlişkileri}

Katılımcıların kültürlenmenin bütünleşme alt boyutundan aldıkları toplam puanların, cinsiyet, medeni durum, yaş, Türkiye'deki ikamet süresi, geldiği ülke, ülkesinde ikamet ettiği yerleşim birimi, öğrenim gördüğü alan, Türkiye'de nerde oturduğu ve Türkiye'de beraber ikamet ettikleri kişi değişkenlerine göre farklılaşıp farklılaşmadığına bakılmıştır.

Tablo 8. Bütünleşme Puanlarının Cinsiyet ve Türkiye'de Oturduğu Yer Değişkenine Göre Karşılaştırılması

\begin{tabular}{llccccc}
\hline \multicolumn{1}{c}{ Değişken } & Düzey & $\mathrm{N}$ & $\overline{\mathrm{X}}$ & $\mathrm{S}$ & $\mathrm{sd}$ & $\mathrm{t}$ \\
\hline \multirow{2}{*}{ Cinsiyet } & Kadın & 88 & 76.38 & 17.42 & \multirow{2}{*}{298} & \multirow{2}{*}{0.72} \\
& Erkek & 212 & 74.74 & 18.16 & & \\
\multirow{2}{*}{ Türkiye'de Oturduğu Yer } & Ev & 228 & 74.23 & 17.74 & \multirow{2}{*}{298} & \multirow{2}{*}{$3.29 *$} \\
& Yurt & 72 & 78.39 & 18.34 & & \\
\hline
\end{tabular}

$* \mathrm{P}<.05$

Tablo 8'de sunulan Bütünleşme puanlarının çeşitli değişkenlere göre karşılaştırılmasına ilişkin bağımsız t testi sonuçları incelendiğinde, yalnızca Türkiye'de oturduğu yer değişkenine göre anlamlı fark olduğu $[\mathrm{t}(298)=3.29$; $\mathrm{p}<.05]$ görülmektedir. Türkiye'de oturduğu yer göre grupların ortalamaları incelendiğinde, yurtta oturanların ortalamasının $(\overline{\mathrm{X}}=78.39)$, evde oturanların ortalamasından ( $\overline{\mathrm{X}}=74.23)$ yüksek olduğu görülmektedir. Bu bulgu yurtta oturanların bütünleşme stratejisini tercih etme oranlarının daha fazla olduğunu göstermektedir. Diğer değişkene göre ise anlamlı fark yoktur.

Tablo 8'de görüldüğü gibi bütünleşme puanlarının cinsiyete göre farklılaşmadığı bulunmuştur [t(298) = .72; p> .05]. Ama Kim vd. (2001)' nın çalışmasında farklı bir sonuç çıkmıştır. Kadınların yeni girdikleri grupta kendi kültürel özelliklerini 
devam ettirirken, yeni kültürel grupla da etkileşime girme eğiliminde oldukları tespit edilmiştir.

Tablo 8'de Türkiye'de oturulan yer değişkenine bakıldığında, yurtta oturan katılımcıların bütünleşme puanlarının evde oturanlara göre yüksek olduğu görülmektedir. Yalnız kalma riskinin az olması, güvenliğin olması, öğrencilikte önemli yeri olan ders notu bulmanın kolay olması, her çevreden kendinize uygun arkadaş bulmak mümkün olması, değişik kültürlerden arkadaşlarının olması, değişik eğlenceler düzenlenerek kaynaşmanın sağlanması yurtta yaşayan katılımcıların bütünleşme puanlarının artmasına bir etken olduğu söylenebilir.

Öte yandan yabancı öğrencilerin yurtta benzer problemleri yaşamaları, aynı hayatı paylaşmaları da bütünleşme puanlarını artırdığı söylenebilir. Annaberdiyev (2006)'e göre yabancı öğrencilerin çoğunun devlet yurtlarında kalıyor ve benzer sıkıntıları yasıyor olabilecekleri, benzer oranda psikolojik uyum düzeylerine sahip oldukları seklinde yorumlanabilir. Özgüven (1990)'in yaptığı çalışmada, yurtlarda kalan üniversite öğrencilerinin gerilim, aşırı kaygı, aşırı uykusuzluk, duygusal kararsızlık, sürekli hayal kurma, aşırı heyecan ve aşırı alınganlık gibi birtakım psikolojik problemler yasadıkları bulunmuştur. Buna karşın Esentürk (1998)'ün yaptığı çalışmada, evde kalan yabancı uyruklu öğrencilerin sorunlarının, yurtta kalan öğrencilerin sorunlarından fazla olduğu belirtilmektedir.

Tablo 9. Bütünleşme Puanlarının Çeşitli Değişkenlere Göre Karşılaştırılması

\begin{tabular}{|c|c|c|c|c|c|c|c|}
\hline Değişken & Düzey & $\mathrm{N}$ & $\bar{X}$ & $\mathrm{~S}$ & $\mathrm{sd}$ & $\mathrm{F}$ & $\begin{array}{c}\text { Anlaml } \\
\text { fark } \\
\text { (Scheffe } \\
\text { testi) }\end{array}$ \\
\hline \multirow{3}{*}{$\begin{array}{l}\text { Medeni } \\
\text { Durum }\end{array}$} & 1. Evli & 17 & 129.70 & 12.79 & \multirow{3}{*}{2,29} & \multirow{3}{*}{$3.40 *$} & \multirow{3}{*}{$1-2$} \\
\hline & 2. Bekar & 277 & 118.86 & 17.78 & & & \\
\hline & 3. Dul & 6 & 113.83 & 7.73 & & & \\
\hline \multirow{3}{*}{ Yaş } & 1. 17-25 yaş & 204 & 117.01 & 17.23 & \multirow{3}{*}{2,29} & \multirow{3}{*}{$5.99 *$} & \multirow{3}{*}{$1-2$} \\
\hline & 2. $26-33$ yaş & 89 & 124.30 & 17.36 & & & \\
\hline & 3. $34-45$ yaş & 7 & 125.71 & 17.40 & & & \\
\hline \multirow{4}{*}{$\begin{array}{l}\text { Türkiye'de } \\
\text { Kalış } \\
\text { Süresi }\end{array}$} & $1.05-10 \mathrm{y} 1 \mathrm{l}$ & 184 & 114.79 & 16.57 & \multirow{4}{*}{3,29} & \multirow{4}{*}{$13.85^{*}$} & \multirow{4}{*}{$\begin{array}{l}1-2 \\
1-3\end{array}$} \\
\hline & 2. $11-15$ y1l & 82 & 124.52 & 16.47 & & & \\
\hline & 3. $16-20 \mathrm{yll}$ & 24 & 132.91 & 15.20 & & & \\
\hline & 4. $21-25$ y1l & 10 & 129.00 & 19.25 & & & \\
\hline Gelinen & 1. Kafkasya & 186 & 123.00 & 16.74 & \multirow{3}{*}{2,29} & \multirow{3}{*}{$15.73^{*}$} & \multirow{3}{*}{$\begin{array}{l}1-3 \\
2-3\end{array}$} \\
\hline Ülke / & 2. Avrupa & 51 & 118.56 & 16.78 & & & \\
\hline Bölge & 3. Ortadoğu & 63 & 109.33 & 16.78 & & & \\
\hline \multirow{3}{*}{$\begin{array}{l}\text { Yerleşim } \\
\text { Birimi }\end{array}$} & 1. Köy & 21 & 123.95 & 15.73 & \multirow{3}{*}{2,29} & \multirow{3}{*}{1.24} & \multirow{3}{*}{ - } \\
\hline & 2. Kasaba & 23 & 115.60 & 15.15 & & & \\
\hline & 3. Şehir & 256 & 119.34 & 17.87 & & & \\
\hline & 1. Dil & 17 & 132.88 & 14.43 & & & \\
\hline Öğrenim & 2. Sağlık & 81 & 116.87 & 13.85 & \multirow{4}{*}{4,29} & \multirow{4}{*}{$6.01 *$} & $1-2$ \\
\hline Gördükleri & 3. Sosyal & 168 & 120.84 & 17.13 & & & $1-4$ \\
\hline \multirow[t]{3}{*}{ Alan } & 4. Fen & 9 & 103.33 & 16.40 & & & $1-5$ \\
\hline & 5. Mühendislik & 25 & 114.24 & 25.33 & & & \\
\hline & 1. Kendi vatandaş 1 & 120 & 117.45 & 16.41 & 3,29 & 2.56 & - \\
\hline
\end{tabular}




\begin{tabular}{lllll} 
Birlikte & 2. T.C vatandaşı & 67 & 117.59 & 20.10 \\
İkamet & 3. Yalnız & 27 & 126.59 & 15.29 \\
Ettiği kişi & 4. Diğer & 86 & 121.18 & 17.17 \\
\hline
\end{tabular}

$* \mathrm{P}<.05$

Tablo 9'da sunulan Bütünleşme puanlarının çeşitli değişkenlere göre karşılaştırılmasına ilişkin tek yönlü ANOVA sonuçları incelendiğinde medeni durum $[\mathrm{F}(2.297)=3.40 ; \mathrm{p}<.05]$, yaş $[\mathrm{F}(2.297)=5.99 ; \mathrm{p}<.05]$, Türkiye'de kalış süresi $[\mathrm{F}(3.296)=13.85 ; \mathrm{p}<.05]$, gelinen ülke/bölge $[\mathrm{F}(2.297)=15.73 ; \mathrm{p}<.05]$ ve öğrenim gördükleri alan $[\mathrm{F}(4,295)=6.01 ; \mathrm{p}<.05]$ değişkenlerine göre anlaml fark olduğu görülmektedir. Farkın kaynağını bulmak üzere uygulanan Scheffe Testi sonuçları incelendiğinde, medeni duruma göre 1.evli ve 2.bekar olanlar; yaşa göre 1.17-25 yaş ve 2.26-33 yaş aralığında olanlar; Türkiye'de kalış süresine göre 1.5-10 y1l ve 2.11-15 yıl; $1.5-10$ y1l ve 3.16-20 yıldır Türkiye'de olanlar; gelinen ülkeye/bölgeye göre 1.Kafkasya ve 3.Ortadoğu; 2.Avrupa ve 3.Ortadoğu'dan gelenler; öğrenim gördükleri alana göre 1.Dil ve 2.Sağlık; 1.Dil ve 4.Fen; 1.Dil ve 5.Mühendislik farklarının anlamlı olduğu belirlenmiştir. Diğer değişkenine göre ise anlamlı fark yoktur.

Tablo 9'da evli katılımcıların bütünleşme puanlarının yüksek olduğu görülmektedir. Bireyin evlenince o ülkeyi kendi evi gibi gördüğü orada yaşamaya başlayınca alıştı̆̆ı ve kabullendiği söylenebilir. Bu bulgu alan yazındaki bulgularla desteklenmektedir. Khairullah ve Khairullah (1999)'a göre kendi etnik kökenlerinden farklı bir etnik kökene sahip bireyle evlenen göçmenler, kendi etnik kökeninden biriyle evlenen göçmenlere göre daha hızlı kültürlenmektedir.

Tablo 9'da bakıldığında, yaşın ilerlemesinin bütünleşme puanlarını artırdığı görülmektedir. Yaş ilerledikçe kültürel farklılıkları kabullenmenin ve kültürel deneyimlerin artmasının bütünleşmeyi kolaylaştırdığı söylenebilir. Bu bulgu alan yazındaki bilgilerle de örtüşmektedir. Şeker (2006) yaptığı araştırmada, yaş değişkenine göre bütünleşme alt boyutundan alınan toplam puanların farklılaşıp farklılaşmadığını görmek için yaptığı analizde; üç yaş grubu arasında anlamlı bir farklılaşma olduğunu bulmuştur. Karşılaştırma sonuçlarına göre üçüncü grupta bulunan 44 yaş ve üzeri katılımcıların bütünleşme alt boyutundan aldıkları toplam puan ortalaması ile 18-27 yaş ve 28-43 yaş katılımcıların aldıkları toplam puan ortalamaları arasında istatistiksel açıdan anlamlı bir farklılaşma olduğu gözlenmiştir. Daha yaşıı katılımcıların genç gruplara göre daha fazla bütünleşme stratejisini tercih ettikleri saptanmıştır.

Tablo 9'da Türkiye'de kalış süresi ile bütünleşme puanları arasında farklılaşma olduğu görülmektedir. Türkiye'de daha çok zaman geçirmiş olmanın bütünleşme puanlarını artırdığı görülmektedir. Bu bulgu alan yazındaki araştırmalarla da örtüşmektedir. Şeker (2006)'in yaptığ1 araştırmada, bütünleşme alt boyutundan alınan toplam puanların katılımcıların ikamet süresine göre farklılaşıp farklılaşmadığına bakmak için yapılan analize göre bu gruplar arasında anlamlı bir farklılaşma olduğu görülmektedir. Yani, daha uzun süre ikamet eden katılımcıların bütünleşme stratejisini daha fazla kullandıkları saptanmıştır. 
Türkiye'de daha uzun zaman geçiren katılımcılar genelde yüksek lisans ve doktora öğrencilerinden oluşmaktadır. $\mathrm{Bu}$ da eğitim düzeyi yükseldikçe bütünleşme artmaktadır şeklinde yorumlanabilir. Benzer şekilde Ataca ve Berry (2002), tarafından Kanada' da yaşayan Türkler ile yapılan çalışma sonucunda da eğitim düzeyi daha yüksek olan göçmenlerin bütünleşme stratejilerini tercih ettikleri ortaya konmuştur. $\mathrm{Bu}$ araştırmaya göre eğitim durumundaki artış ile ayrılma stratejisini tercihinin ters orantılı olduğu ifade edilebilir.

Tablo 9'da bütünleşmenin gelinen ülkeye göre farklılaştığ 1 görülmektedir. Kafkasya'daki ülkeler, Türk kültürüne daha yakın olan akraba topluluklardan gelen öğrencilerden oluşmaktadır. Dolayısıyla bu gruptan gelen öğrencilerin kültürlerinin Türk kültürüne benzerliği, bütünleşmeyi artırmaktadır şeklinde yorumlanabilir. Karaoğlu (2007) da yaptığı araştırmada kültür benzerliğinin uyumdaki olumlu etkisini doğrulamıştır. Benzer bir şekilde Bektaş vd. (2006) yaptıkları çalışmada, uluslararası öğrencilerin Türkiye'ye uyum sağlamalarında, kültürel benzerliğin olumlu etkisinin olduğu bulunmuştur.

Tablo 9'daki öğrenim gördükleri alan değişkenine bakıldığında, dil alanında öğrenim gören katılımcıların bütünleşme puanlarının diğer alanlarda eğitim görenlere göre daha yüksek olduğu görülmektedir. Asutay (2007)'ya göre “Dilin yalnızca göstergeler dizgesi değil, aynı zamanda bir kültür olduğu kabul edilirse, dil ile kültürün birbirinden ayrı düşünülemeyeceği görülür. $O$ halde, dil öğrenimi ve öğretiminde 'kültür' unsurunu hiçbir zaman unutmamak gereklidir. Dil, bir göstergeler dizgesi olduğuna göre, o dizge içerisinde yer alan her göstergenin, dış dünyada işaret ettiği bir gönderme alanı da kültürle ilgilidir. Göstergelerin anlamları da bu şekilde oluşmakta, kültür öğesi ile tamamlanmaktadır". Buradan da anlaşıldığı gibi dil öğrenimi sonucu edinilen dil sadece bir iletişim vasıtası değil kültürlenmeyi dolayısıyla bütünleşmeyi kolaylaştıracak en önemli ögedir denebilir.

\subsection{Kültürlenme ile Demografik Değişkenlerin İlişkileri}

Katılımcıların kültürlenme ölçeğinden alınan toplam puanın, cinsiyet, medeni durum, yaş, Türkiye'deki ikamet süresi, geldiği ülke, ülkesinde ikamet ettiği yerleşim birimi, öğrenim gördüğü alan, Türkiye'de nerde oturduğu ve Türkiye'de beraber ikamet ettikleri kişi değişkenlerine göre farklılaşıp farklılaşmadığına bakılmıştır.

Tablo 10. Kültürlenme Puanlarının Cinsiyet ve Türkiye'de Oturduğu Yer Değiş̧kenine Göre Karşılaştırılması

\begin{tabular}{lcccccc}
\hline \multirow{2}{*}{ Değişken } & Düzey & $\mathrm{N}$ & $\overline{\mathrm{X}}$ & $\mathrm{S}$ & \multirow{2}{*}{ sd } & \multirow{2}{*}{$\mathrm{t}$} \\
\hline \multirow{2}{*}{ Cinsiyet } & Kadın & 88 & 258.90 & 23.26 & \multirow{2}{*}{298} & \multirow{2}{*}{0.46} \\
& Erkek & 212 & 260.35 & 25.37 & & \\
\multirow{2}{*}{ Türkiye'de Oturduğu Yer } & Ev & 228 & 260.17 & 25.09 & \multirow{2}{*}{298} & \multirow{2}{*}{0.30} \\
& Yurt & 72 & 259.15 & 23.74 & \multirow{2}{*}{} \\
\hline
\end{tabular}


Tablo 10'da sunulan Kültürlenme puanlarının çeşitli değişkenlere göre karşılaştırılmasına ilişskin bağımsız $\mathrm{t}$ testi sonuçları incelendiğinde, ayrılmanın cinsiyet ve Türkiye'de oturulan yer değişkenine göre farklılık göstermediği görülmektedir.

Tablo 10'da da görüldüğü gibi kültürlenme puanlarının cinsiyete göre farklılaşmamaktadır $[\mathrm{t}(298)=0.46 ; \mathrm{p}>0.05]$. Bu bulgu, kültürlenmenin cinsiyet değişkeninden etkilenmediği şeklinde yorumlanabilir. Benzer şekilde Gün ve Bayraktar (2008) da yaptığı araştırmada göç etmiş ergenlerin kültürlenme düzeylerini cinsiyet ve yaş açısından karşılaştırılmış, anlamlı farklılıklar bulunamamıştır. Ama Leong ve Tata (1990) araştırmalarında, katılımcıların kültürlenme tercihlerinin cinsiyete göre farklılaştığı sonucuna ulaşmışlardır. Araştırmada kadınların kültürlenme düzeyleri erkeklere göre daha yüksek bulunmuştur.

Tablo 11. Kültürlenme Puanlarının Çeşitli Değiş̧kenlere Göre Karşılaştırılması

\begin{tabular}{|c|c|c|c|c|c|c|c|}
\hline Değişken & Düzey & $\mathrm{N}$ & $\overline{\mathrm{X}}$ & $S$ & sd & $\mathrm{F}$ & $\begin{array}{c}\text { Anlamli } \\
\text { fark } \\
\text { (Scheffe } \\
\text { testi) }\end{array}$ \\
\hline \multirow{3}{*}{$\begin{array}{l}\text { Medeni } \\
\text { Durum }\end{array}$} & 1. Evli & 17 & 249.17 & 18.38 & \multirow{3}{*}{2,29} & \multirow{3}{*}{$3.45^{*}$} & \multirow{3}{*}{$1-2$} \\
\hline & 2. Bekar & 277 & 260.97 & 25.03 & & & \\
\hline & 3. Dul & 6 & 242.16 & 9.62 & & & \\
\hline \multirow{3}{*}{ Yaş } & 1. $17-25$ yaş & 204 & 261.07 & 25.02 & \multirow{3}{*}{2,29} & \multirow{3}{*}{0.94} & \multirow{3}{*}{ - } \\
\hline & 2. $26-33$ yaş & 89 & 258.00 & 24.78 & & & \\
\hline & 3. $34-45$ yaş & 7 & 251.00 & 10.92 & & & \\
\hline \multirow{4}{*}{$\begin{array}{l}\text { Türkiye'de } \\
\text { Kalış Süresi }\end{array}$} & $1.05-10 \mathrm{y} 11$ & 184 & 262.25 & 24.95 & \multirow{4}{*}{3,29} & \multirow{4}{*}{1.92} & \multirow{4}{*}{-} \\
\hline & 2. $11-15 \mathrm{y} 1 \mathrm{l}$ & 82 & 256.89 & 24.69 & & & \\
\hline & 3. $16-20 \mathrm{y}_{1}$ & 24 & 251.54 & 19.47 & & & \\
\hline & 4. $21-25 \mathrm{y} 11$ & 10 & 262.30 & 28.69 & & & \\
\hline Gelinen & 1. Kafkasya & 186 & 260.20 & 23.59 & \multirow{3}{*}{2,29} & \multirow{3}{*}{0.30} & \multirow{3}{*}{-} \\
\hline Ülke / & 2. Avrupa & 51 & 261.37 & 30.81 & & & \\
\hline Bölge & 3. Ortadoğu & 63 & 257.93 & 22.79 & & & \\
\hline \multirow{3}{*}{$\begin{array}{l}\text { Yerleşim } \\
\text { Birimi }\end{array}$} & 1. Köy & 21 & 257.57 & 30.25 & \multirow{3}{*}{2,29} & \multirow{3}{*}{0.21} & \multirow{3}{*}{ - } \\
\hline & 2. Kasaba & 23 & 257.78 & 25.67 & & & \\
\hline & 3. Şehir & 256 & 260.31 & 24.24 & & & \\
\hline \multirow{5}{*}{$\begin{array}{l}\text { Öğrenim } \\
\text { Gördükleri } \\
\text { Alan }\end{array}$} & 1. Dil & 17 & 268.94 & 22.21 & \multirow{5}{*}{4,29} & \multirow{5}{*}{$2.81 *$} & \multirow{5}{*}{$\begin{array}{l}1-2 \\
1-4\end{array}$} \\
\hline & 2. Sağlık & 81 & 253.92 & 24.41 & & & \\
\hline & 3. Sosyal & 168 & 261.41 & 24.90 & & & \\
\hline & 4. Fen & 9 & 250.11 & 15.08 & & & \\
\hline & 5. Mühendislik & 25 & 266.84 & 25.24 & & & \\
\hline \multirow{4}{*}{$\begin{array}{l}\text { Birlikte } \\
\text { İkamet } \\
\text { Ettiği kişi }\end{array}$} & 1. Kendi vatandaş1 & 120 & 261.29 & 23.08 & \multirow{4}{*}{3,29} & \multirow{4}{*}{0.40} & \multirow{4}{*}{-} \\
\hline & 2. T.C vatandaş1 & 67 & 258.11 & 25.93 & & & \\
\hline & 3. Yalnız & 27 & 256.74 & 29.90 & & & \\
\hline & 4. Diğer & 86 & 260.44 & 24.54 & & & \\
\hline
\end{tabular}

$* \mathrm{P}<0.05$

Tablo 11'de sunulan Bütünleşme puanlarının çeşitli değişkenlere göre karşılaştırılmasına ilişkin tek yönlü ANOVA sonuçları incelendiğinde medeni 
durum $[F(2.297)=3.45 ; p<0.05]$ ve öğrenim gördükleri alan $[F(4,295)=2.81 ; p<$ 0.05] değişkenlerine göre anlamlı fark olduğu görülmektedir. Farkın kaynağını bulmak üzere uygulanan Scheffe Testi sonuçları incelendiğinde, medeni duruma göre 1.evli ve 2.bekar olanlar; öğrenim gördükleri alana göre 1.Dil ve 2.Sağlık; 1.Dil ve 4.Fen farklarının anlamlı olduğu belirlenmiştir. Diğer değişkenine göre ise anlamlı fark yoktur.

Tablo 11'de görüldüğü gibi, bekar olmak kültürlenme puanlarını artırmaktadır. Bu durum, evli katılımcıların ailevi sorumluluklarının daha fazla olması, bakmakla yükümlü oldukları çocuklarının bulunması, vb. gibi nedenlerden dolayı, Türkiye'den beklentilerinin, bekar katılımcılara göre daha yüksek olmasından kaynaklanıyor olabilir. Diğer yandan Şeker (2006)'in yaptı̆̆ 1 araştırmadan bekarların daha çok asimilasyonu, evlilerin ise daha çok bütünleşmeyi tercih ettiği görülmüştür.

Tablo 11'e bakıldığında, dil alanında öğrenim gören katılımcıların kültürlenme puanlarının diğer alanlarda eğitim görenlere göre yüksek olduğu görülmektedir. Bir insanın hem ana dilini konuşması hem de bir başka dilde öğrenim görmesi kültürel yakınlaşmayı ve zenginliği gösterir. Bireylerin farklı kültürel özelliklere hoşgörü ve saygıyla bakmaları, toplumsal uyumun ve beraberliğin sağlanmasında önemli olduğu söylenebilir.

Bilgi ve toplum ilişkisinde dil ve kültürün birlikteliği, aynı zamanda dil ve kültür sayesinde toplumun kendisini tanımasına ve diğer toplumlarla olan farkını, farklılığını algılamasına yol açmaktadır (Yeşildağ, 2008). Dilin anlaşılması, düşüncenin anlaşılmasında da önemli rol oynar. İnsanlar kendi kişisel düşüncelerini anlatmak ve başkalarıyla paylaşmak isterler. Bunun için de dilden yararlanırlar (Külebi, 1994).

Yeşildağ (2008)'in dil sorunu yaşayan katılımcıların o ülkedeki komşu ve arkadaşlarıyla görüşme oranı, dil sorunu yaşamayan katılımcılara göre daha düşüktür. Dil problemi yaşanan ülkeye uyumu zorlaştıran bir faktör olarak görülmektedir. Çünkü o ülkenin dilini konuşanlarla iletişim problemi uyumun olumlu anlamda gelişmesine engel olmaktadır. Dil probleminden dolayı iletişim kuramamakta, iletişim sorununa bağlı olarak da karşılıklı güvensizlik oluşmaktadır. Bu güvensizlik üzerine de olumlu bir ilişki tesis edilememektedir. Diyalog kurulamayan bir toplumla uyum içinde yasamak mümkün olmamaktadır.

\section{SONUÇ VE TARTIŞMA}

Kültürlenme kavramı, yapılan çalışmalarda genel olarak bireylerin ve grupların bir diğer kültür ile uzun süreli etkileşimleri sonucunda meydana gelen psikolojik ve davranışsal değişim süreci olarak tanımlanmaktadır. İnsanlar hayatlarında sürekli olarak farklı kültürel ortamlara girerek hayatlarını sürdürürler. Bu kültürel ortamlar insanların bilişinin, davranış ve duygularını düzenler (Kim vd., 2001; Sam, 1992). Yani insanlar arasında sürekli sosyal etkileşim aracılığı ile değişim sürer. Bireyler aynı anda farklı kültürlerin içinde bulunurlar ve sürekli değişim yaşarlar. 
$\mathrm{Bu}$ araştırmadan elde edilen bulgular, kültürlenmenin ve onun alt boyutları olan asimilasyon, ayrılma ve bütünleşmenin çeşitli değişkenlere göre farklılaştığını göstermiştir.

Katılımcıların medenî durumuna göre bakıldığında: asimilasyon, ayrılma ve bütünleşme stratejilerinde farklılaşma yaşanmaktadır. Bekar grubun asimilasyon stratejisini daha fazla tercih ettiği söylenebilir. Benzer bir şekilde, Şeker (2006)'in yaptığ 1 araştırmada da evli ve bekar katılımcıların asimilasyon alt boyutundan aldıkları toplam puan ortalamaları arasında anlamlı bir fark olduğu bulunmuştur. Araştırma sonucunda bekar katılımcıların daha fazla asimile oldukları gözlemlenmiştir. Bütünleşme stratejisinde de evli ve bekarlar arasında farklılaşma gözlenmemiş ancak evli grubun bu stratejiyi daha fazla tercih ettiği saptanmıştır. Khairullah ve Khairullah (1999)'a göre kendi etnik kökenlerinden farklı bir etnik kökene sahip bireyle evlenen göçmenler, kendi etnik kökeninden biriyle evlenen göçmenlere göre daha hızlı kültürlenmektedir. Ayrılma stratejisini bekar grubun evlilerden daha fazla tercih ettiği saptanmıştır. Ama Şeker (2006)'in yaptığı araştırmada farklı sonuçlara ulaşılmıştır. Ayrılma alt boyutundan evli katılımcıların aldıkları toplam puan ortalamasının, bekar katılımcıların aldıkları toplam puan ortalamasından anlamlı şekilde farklı olduğu, bu stratejiyi evli katılımcıların daha fazla tercih ettikleri saptanmıştır.

Yaş değişkeni açısından incelendiğinde; bütünleşme ve ayrılama stratejisinde farklılaşma olduğu, asimilasyon stratejisinde ise farklılaşma olmadığ gözlenmiştir. Yaş arttıkça bütünleşme stratejisinin daha fazla tercih edildiği saptanmıştır. İnsanların yaşları ilerledikçe kendi kültürel özelliklerini korurken, yeni girdikleri kültürel ortam özellikleri ile de etkileşime girdikleri ifade edilebilir. $\mathrm{Bu}$ bulgu alan yazındaki bilgilerle de örtüşmektedir. Şeker (2006)'in yaptığı araştırmada, yaş değişkenine göre bütünleşme alt boyutundan alınan toplam puanların farklılaşıp farklılaşmadığına bakılmış ve üç yaş grubu arasında anlamlı bir farklılaşma olduğu görülmüştür. Üçüncü grupta bulunan 44 yaş ve üzeri katılımcıların bütünleşme alt boyutundan aldıkları toplam puan ortalaması ile 1827 yaş ve 28-43 yaş katılımcıların aldıkları toplam puan ortalamaları arasında istatistiksel açıdan anlamlı bir farklılaşma olduğu gözlenmiştir. Daha yaşlı katılımcıların genç gruplara göre daha fazla bütünleşme stratejisini tercih ettikleri saptanmıştır.

Öte yandan yaş küçülmesi bütünleşmenin tam tersine sonuçların çıkmasına neden olmaktadır. Yaşı diğer gruplara göre daha küçük olan katılımcıların (17-25 yaş) ayrılma stratejisini daha çok tercih ettikleri görülmüştür. Aileye bağlllık, çocuklarının olması, farklı ülke deneyiminin azlığı, işinin ülkesinde olması gibi nedenler de katılımcılarım ayrılma stratejisini tercih sebebi olabilir. Farklı olarak Yeşildağ (2008) yaptığı araştırmada, 16-35 yaş arasındaki katılımcıların Avusturya toplumuna uyum sorunu yaşama oranları 35 yaş ve üzeri olanlara göre daha düşük olduğu görülmüştür. Yaşı ileri olanların uyum sorununun gençlere göre daha fazla olduğu saptanmıştır. 
Bu çalışmada karşılaşılan en ilginç sonuçlardan birisi asimilasyon ve Türkiye'de kalış süresiyle ilgilidir. Türkiye'de kalış süresi, diğer gruplara göre daha az (0510 yıl) olan katılımcıların daha çok asimile olduğu görülmüştür. Alan yazındaki çalışmalar tam tersini göstermektedir. Çalışmalara bakıldığında bir yerde kalış süresiyle asimilasyonun doğru orantılı olduğu görülmektedir. Yeşildağ (2008)'ın yaptığı araştırmada Avusturya'da 10 yıl ve daha az zaman yaşayanların uyum sorunu yaşama oranı 11 yıl ve daha fazla, Avusturya'da yaşayanlara göre daha yüksek bulunmuştur. Avusturya'ya göç edenlerin uyum döneminin oldukça uzun sürdüğü ve bu süreçte ciddi sorunlar yaşadıkları saptanmıştır.

Bunun yanında Türkiye'de kalış süresiyle ayrılma ilişkisine bakıldığında, ülkede daha az kalan katılımcıların (05-10yıl) ayrılma stratejisini daha çok tercih ettikleri görülmektedir. $\mathrm{Bu}$ bulgu alan yazındaki bulgularla örtüşmektedir. Gün ve Bayraktar'a (2008) göre de geri dönmeyi düşünen biri, göç ettiği toplumu tanımaya, uyum sağlamaya çaba göstermeyecek, ilişkilerini ve hazırlıklarını geri dönmeye yönelik yapacaktır. Göç ettiği toplumun sosyal, kültürel değerlerine mesafeli durabilecek ve öğrenmeye gayret etmeyecektir. Türkiye'de kalış süresi uzun olanların ise bütünleşme stratejisini tercih ettiği görülmektedir. Bu bulgu alan yazındaki çalışmalarla paralellik göstermektedir. Şeker'in (2006) yaptı̆̆ araştırmada, bütünleşme alt boyutundan alınan toplam puanların katılımcıların ikamet süresine göre farklılaşıp farklılaşmadığına bakılmıştır ve bu gruplar arasında anlamlı bir farklılaşma olduğu görülmüştür. Yani, daha uzun süre ikamet eden katılımcıların bütünleşme stratejisini daha fazla benimsedikleri saptanmıştır. Annaberdiyev (2006) yabancı uyruklu öğrencilerin sorunlarının Türkiye'ye geliş yılına göre farklılık gösterdiğini vurgulamıştır. Araştırmasında, Türkiye’de 1 yıl süreyle kalan yabancı uyruklu öğrencilerin sorunları, Türkiye'de 3 yıl süreyle kalan öğrencilerin sorunlarından daha fazla olduğu ortaya koymuş ve bu durumu, öğrencilerin ilk defa ailesinden ve ülkesinden uzakta yaşamalarına, farklı okul sisteminin yarattı̆̆ gerilimlere bağlamıştır.

Ayrıca araştırmada Türkiye'de uzun süre kalan katılımcıların genelde doktora ve yüksek lisans öğrencisi olduğu görülmektedir. Eğitim seviyesi arttıkça bütünleşme puanlarının yükseldiği söylenebilir. Ataca ve Berry (2002), tarafından Kanada'da yaşayan Türkler ile yapılan çalışma sonucunda da eğitim düzeyi daha yüksek olanların bütünleşme stratejilerini tercih ettikleri ortaya konmuştur. Bu araştırma sonucuna göre eğitim durumundaki artış ile ayrılma stratejisi tercihinin ters orantılı olduğu ifade edilebilir. Bektaş vd. (2006) yaptıkları çalışmada, öğrencilerin Türkiye'de kalma sürelerinin fazla olmasının, Türk kültürüne yaklaşmalarında etkili olduğunu belirlemişlerdir. Benzer şekilde Quester ve Chong (2001)'a göre bireylerin ülkede yaşadığ 1 süre arttıkça mevcut kültürle daha fazla etkileşime girerek o kültüre daha fazla entegre olacaklardır. Çünkü bir kültüre maruz kalma süresi kültürlenme derecesi ile pozitif yönlü bir ilişkiye sahiptir. Aynı şekilde bu çalışmanın sonucuna bakıldığında Türk Cumhuriyetleri öğrencilerinin belirli süre geçtikten sonra Türk kültürünü benimsemesiyle kültürlenme tutumlarının değiştiği söylenebilir. 
Kafkasya'dan gelen katılımcıların kültürlenme stratejilerinden özellikle bütünleşme stratejisini, Ortadoğu'dan ve Avrupa'dan gelen katılımcılara göre daha belirgin olarak tercih ettikleri saptanmıştır. Avrupa'dan gelen grubun asimilasyonu tercih ettiği gözlenmiştir. Bütünleşmeyi tercih eden birey kendi kültürel özelliklerini sürdürürken, baskın kültürel grupla da etkileşime girmeye eğilimlidir. Ayrılmayı tercih eden, birey baskın olmayan kendi öz kültürünü iyice yerleştirip, diğer kültürler ile etkileşime girmekten kaçınır. Asimilasyon stratejisinde ise, bireyler kendi kültürel kimliklerini devam ettirmek istemeyip, diğer kültürle ilişki arayışındadırlar (Berry, 1992). Baskın grubun belirli bir kültürlenme stratejisi tercihinin olup olmadığı ve kültürlenen grubun tercih ettiği kültürlenme stratejisinin bilinmesi oldukça önemlidir. Her iki grubun tercih ettiği strateji arasında benzerlik ne kadar fazla ise yeni gelen grubun uyumunun o derece yüksek olması beklenir (Hovey, 2000). Kültürlenen bireylerin çoğunda, yeni kültürel bağlama uyum önemli bir konudur. Bu uyum faktörlerin türüne bağlı olarak çok farklı biçimde olabilir. Bazen başat kültür ile kültürlenen birey arasında uyum yüksektir (örn: asimilasyon veya bütünleşme stratejileri). Bazen ise uyum yüksek olmaz (örn: ayrılma stratejisi) (Berry ve Sam, 1997). Tomich vd. (2003), Amerika'daki Asyalı ve Avrupalı öğrencilerin uyum farklılı̆̆ını belirlemeye çalışmışlardır. Asyalı ve Avrupalı grupların uyum düzeylerinde, anlamlı düzeyde farklılık olduğu, yani Asyalı öğrencilerin Avrupalı öğrencilere göre daha fazla gergin oldukları ve daha fazla sorunlu oldukları bulunmuştur. Araştırmacılar bu durumun, kültürel benzerlik veya uzaklığa bağlı olduğunu, Avrupa yaşamının Amerikan yaşamına benzer olmasından böyle bir sonucun ortaya çıkmış olabileceğini ileri sürmüşlerdir. Ayrıca, Bektaş vd. (2006) de araştırmalarında, yabancı uyruklu öğrenci temsilcileriyle yaptığı görüş̧mesi sonucunda, yabancı öğrencilerin kültürel benzerliğinin Türkiye'ye uyum sağlamalarında olumlu etkisinin olduğunu belirtmişlerdir.

Katılımcıların ülkelerinde oturdukları yerleşim birimi (şehir, kasaba, köy) değişkenine bakıldığında sadece ayrılma puanlarına göre bir farklılaşma olduğu görülmektedir. Asimilasyon ve bütünleşme puanlarıyla değişken arasında herhangi bir farklılaşma saptanmamıştır. Geldikleri ülkede şehirde yaşayan katılımcıların ayrılma puanlarının yüksek olduğu görülmektedir. Kendi ülkesinde köyde yaşayan katılımcıların yaşam olanaklarının şehirde yaşayanlara göre daha düşük olduğunu varsayarsak, geldikleri kentte bu olanaklardan daha fazla yararlanacakları için ayrılma puanları düşmektedir. Bunun yanında kendi ülkesinde şehirde yaşayan katılımcıların geldikleri kentte aynı olanakları bulamaması ayrılma puanlarını yükseltmektedir şeklinde yorumlanabilir.

Uyum sürecinde ortaya çıkabilecek bireysel psikolojik özelliklere sahip olan yabanc1 uyruklu bireyler, sadece yeni bir ortama uyum sağlamak zorunda kalmayıp, aynı zamanda içinde bulundukları yeni kültürün eğitim sistemine de uyum sağlamak zorundadırlar (Antonova, 1998). Öğrencilerin öğrenim gördükleri alanlara bakıldığında asimilasyon ve bütünleşme altboyutunda yaklaşık tüm alanlarda farklılaşma olduğu görülmektedir. Bunun yanında ayrılma alt boyutunda herhangi bir farklılaşma saptanmamıştır. Mühendislik alanında okuyan 
katılımcıların asimilasyon puanları diğer gruplara göre yüksek olduğu görülmektedir. Mezun oldukları alana ülkelerinde yeterli değerin verilmemesi, ortam koşullarından memnuniyetsizlik, mezun olduktan sonra maddi ve manevi beklentilerin karşılanmaması, kişide ve kişinin hayatında oluşturduğu birtakım sorunlar nedeniyle asimilasyon puanlarını artırıcı nedenler olarak görülebilir. Bunun yanında bütünleşme puanlarında en yüksek alan olarak dil görülmektedir. Geldikleri ülkenin dilinde eğitim görmek diğer bölümlerde okuyanlara göre daha avantajlı gözükmektedir. Çünkü dil alanında eğitim görenler, o eğitimi en etkili bir şeklide edinmek ve mezun olmak için mecburen o ülkenin dilini öğrenmek zorunda olduğu söylenebilir. Dilin öğrenilmesiyle kültürel paylaşımların arttığı düşünülebilir. Birey dil sayesinde duygu ve düşüncelerini ne kadar net bir şekilde karşı tarafa iletirse iletişim de o kadar sağlıklı olur denebilir. Günay’a (1995) göre, gerçekte birey kendine özgü davranışlarını, alıcıyla ilgili yaklaşımları kullandığı dil ve dil yetisi aracılığıyla ortaya koyabilecektir. Dil ile birey arsındaki ilişki bireylerin oluşturduğu anlatım biçiminde belli olur. Toplumsal olan dil, söz gibi bireysel değildir. Tek bir kişinin kendine özgü bir dili de yoktur. Verici toplumsal olan dili kendi duygu ve düşüncelerini anlatmak için kullanır.

Katılımcıların o ülkede birlikte ikamet edilen kişi değişkeni açısından incelendiğinde; ayrılma boyutunda farklılaşma olduğu; asimilasyon ve bütünleşme boyutunda ise farklılaşma olmadığı gözlenmiştir. Türkiye'de kendi vatandaşlarıyla ikamet eden kişilerin ayrılma puanlarının yüksek olduğu görülmektedir. Kendi vatandaşlarıyla yaşıyor olmak, aynı kültürü, aynı dili paylaşıyor anlamı taşıdığı düşünülürse, geldikleri ülkedeki insanlarla daha az iletişime girecekleri ve bunun da ayrılma puanlarını yükselteceği söylenebilir. Antonova'nın (1998) yaptığı çalışmada, yurtların uyum sürecini olumsuz etkilediği, bu durumun yurtların çok kalabalık olması ve yurtlardaki olumsuz şartlardan kaynaklandığı şeklinde yorumlanmaktadır. Ayrıca öğrenci yurtlarındaki olumsuz koşulların yanı sıra, yurt içerisindeki birtakım kuralların ergen ve yetişkin düzeydeki bu öğrencilerin bağımsız davranmalarını kısıtladı̆̆ı ve bu yüzden rahatsızlık duydukları düşünülebilir. Bu bulgudan evde kalanların hiçbir sorunu yoktur anlamının çıkarılmaması gerekmektedir. Çünkü Annaberdiyev (2006) evde kalan yabancı uyruklu öğrencilerin sorunlarının yurtlarda kalan öğrencilerin sorunlarından daha fazla olduğunu belirtmiş ve bunu da evde kalan yabancı uyruklu öğrencilerin çevreden daha fazla izole ve sorunlarıyla baş başa kalmış olabileceklerine bağlamıştır. Öte yandan Quester ve Chung (2001)'a göre bireyin köken ülkesiyle bağlantısı ne kadar çoksa, kültürlenme oranı o kadar az olmaktadır ve birey köken ülkesine ziyaret için daha fazla gitmektedir. Bu aynı zamanda bireyin kendi kültürünü devam ettirdiği ve güçlendirdiği anlamına gelmektedir. Kendi ülkesine yapılan ziyaretler bireyin ülkesine olan bağlarını da ortaya koymaktadır. Chung (2006)'a göre kültürlenme perspektifinde zayıf bağlar, asimilasyon ve entegrasyon açısından önemli olmaktadır. $\mathrm{Bu}$ açıdan yaklaşıldığında da güçlü bağlar, daha çok ayrılmayı getirmektedir.

Kültürlenme puanları incelendiğinde ise, kültürlenmenin sadece medeni durum ve öğrenim alanına göre farklılaştığı görülmektedir. Bekar olan katılımcıların 
kültürlenme puanları evli ve dul olanların puanlarına göre yüksek olduğu görülmektedir. Diğer yandan dil alanında öğrenim gören katılımcıların kültürlenme puanları diğer alanlardakinde yüksek olduğu görülmektedir. Bir insanın hem ana dilini konuşması hem de bir başka dilde öğrenim görmesi kültürel yakınlaşmayı ve zenginliği gösterir. Bireylerin farklı kültürel özelliklere hoşgörü ve saygıyla bakmaları, toplumsal uyumun ve beraberliğin sağlanmasında önemli olduğu söylenebilir. Bilgi ve toplum ilişkisinde dil ve kültürün birlikteliği, aynı zamanda dil ve kültür sayesinde toplumun kendisini tanımasına ve diğer toplumlarla olan farkını, farklılığını algılamasına yol açmaktadır (Yeşildağ, 2008). Dilin anlaşılması, düşüncenin anlaşılmasında da önemli rol oynar. İnsanlar kendi kişisel düşüncelerini anlatmak ve başkalarıyla paylaşmak isterler. Bunun için de dilden yararlanırlar (Külebi, 1994).

Grupların kültürlenme strateji tercihleri, içeriğe ve zamana bağlı olarak çeşitlilik gösterebilmektedir. $\mathrm{Bu}$ çalışmada da kültürlenme stratejilerini etkileyen değişkenler ayrı ayrı ortaya konmuştur. Berry ve Sam (1997) kültürlenme strateji tercihleri ile ilgili, kişinin tüm tercihlerinin üstünde bir strateji tercihi olabileceği gibi bulunduğu yere göre strateji tercihlerinde de çeşitlilikler olabilir. Kişi açısından daha önemli / öncelikli alanlarda (ev, geniş aile, etnik toplum gibi) genel yerlerden (iş yeri, kamusal tüm alanlar vb.) daha fazla kültürel süreklilik aranabilir. Kişiler göç ettikleri toplumdaki deneyimleri sonucunda değişik stratejiler keşfederler. Yaşanılan deneyimler sonucunda bireyler kimi stratejileri daha yararlı bulabilir ve benimseyebilirler. Bireyin ya da grubun tercih ettiği kültürlenme stratejisinin baskın grup tarafından kabul edilip edilmemesi kültürlenme süreci açısından önemlidir.

\section{KAYNAKÇA}

Açıkalın, A., Demirel, Ö., \& Önsoy, R. (1996). Türkiye'de yüksek öğrenim gören Türk Cumhuriyetleri ögrencilerinin sorunları. Yayımlanmamış araştırma raporu, Ankara: Hacettepe Üniversitesi.

Annaberdiyev, D. (2006). Türkiye'de Eğitim Gören Türk Cumhuriyetleri ve Türk Üniversite Öğrencilerinin Psikolojik Yardım Arama Tutumları, Psikolojik İhtiyaçları ve Psikolojik Uyumlarının Bazı Değişkenler Açısından İncelenmesi. Yayımlanmamış Yüksek Lisans Tezi. İzmir: Ege Üniversitesi Sosyal Bilimler Enstitüsü.

Antonova, W. B. (1998). Yabancı ögrencilerin Moskova'da yaşam ve eğitim koşullarına psikolojik uyumları. Uluslararası Eğitim Merkezi, MV Lomonosov adına Moskova Devlet Üniversitesi, Moskova.

Asutay, H. (2007). Dil, Kültür ve Eğitim. Konya: Eğitim Kitabevi.

Ataca, B., \& Berry, J. W. (2002). Psychological, sociocultural, and marital adaptation of Turkish immigrant couples in Canada. International Journal of Psychology, 37(1), 13-26. doi: 10.1080/00207590143000135 
Bektaş, Y., Kocabaş, Ö. E., \& Annaberdiyev, D. (2006). Psychological adaptation and acculturation of the international students in Turkey. In 18th International Congress of the International Association for Cross-Cultural Psychology, Spetses Island, Greece.

Berry, J. W. (1992). Acculturation and adaptation in a new society. International migration, 30(s1), 69-85. doi: 10.1111/j.1468-2435.1992.tb00776.x

Berry, J. W. (1994). Ecology of individualism and collectivism. In U. Kim, H. C. Triandis, C. Kagitcibasi, S.-C. Choi, \& G. Yoon (Eds.), Individualism and collectivism: Theory, method and applications (pp. 77-84). CA: Sage.

Berry, J. W. (1997). Immigration, acculturation, and adaptation. Applied psychology, 46(1), 5-34. doi: 10.1111/j.1464-0597.1997.tb01087.x

Berry, J. W. (1999). Intercultural relations in plural societies. Canadian Psychology, 40(1), 12-21. doi: 10.1037/h0086823

Berry, J. W., \& Sam, D. (1997). Acculturation and adaptation. In J. W. Berry, M. H. Segall, \& C. Kagitcibasi (Eds.), Handbook of cross-cultural psychology, Vol. 3, Social behavior and applications (pp. 291-326). Boston: Allyn and Bacon.

Berry, J. W., Kim, U., Power, S., Young, M., \& Bujaki, M. (1989). Acculturation attitudes in plural societies. Applied psychology, 38(2), 185-206. doi: 10.1111/j.1464-0597.1989.tb01208.x

Berry, J. W., Phinney, J. S., Sam, D. L., \& Vedder, P. (2006). Immigrant youth: Acculturation, identity, and adaptation. Applied psychology, 55(3), 303-332. doi: 10.1111/j.1464-0597.2006.00256.x

Bilgin, N. (1994). Sosyal Bilimlerin Kavşağında Kimlik Sorunu. İzmir: Ege Yayınc1lik.

Bilgin, N. (2003). Sosyal Psikoloji Sözlüğü. İstanbul: Bağlam Yayınc1lık.

Büyüköztürk, Ş. (2002). Sosyal Bilimler İçin Veri Analizi El Kitabı. Ankara: Pegem A Yayıncilık.

Chung, R. H. (2006). Acculturation scales: Asian American Multidimensional Acculturation Scale. In Y. Jackson, (Ed.), Encyclopedia of Multicultural Psychology. Thousand Oaks, CA: Sage Publications.

Cırık, İ. (2008). Çok Kültürlü Eğitim ve Yansımaları. Hacettepe Üniversitesi Eğitim Fakültesi Dergisi, 34, 27-40.

Esentürk, E.L. (1998). Yabancı uyruklu ve Türk Üniversite ögrrencilerine ait sorunların bazı değişkenler açısından incelenmesi. Yayımlanmamış doktora tezi. Ankara: Hacettepe Üniversitesi Sosyal Bilimler Enstitüsü. 
Farver, J. A. M., Narang, S. K., \& Bhadha, B. R. (2002). East meets west: ethnic identity, acculturation, and conflict in Asian Indian families. Journal of Family Psychology, 16(3), 338-350. doi: 10.1037/0893-3200.16.3.338

Gökmen, M. E. (2005). Yabancı Dil Öğretiminde Kültürlerarası İletişimsel Edinç. Dil Dergisi, 128, 69-77.

Gronhaug, K., Gilly, M., \& Penazola, L. (1993). Barriers and incentives in consumer acculturation. European Advances in Consumer Research, 1, 278 286.

Gün, Z., \& Bayraktar, F. (2008). Türkiye'de İç Göçün Ergenlerin Uyumundaki Rolü. Türk Psikiyatri Dergisi, 19(2), 167-176.

Günay, D. (1995). Roman Çözümlemesine Toplum-Dilbilimsel Bir Yaklaşım. Dil Dergisi, 35, 5-24.

Hovey, J. D. (2000). Acculturative stress, depression, and suicidal ideation in Mexican immigrants. Cultural Diversity and Ethnic Minority Psychology, 6(2), 134-151. doi: 10.1037/1099-9809.6.2.134

Huang, Y. C. (2010). Acculturation and academic performance: The role of media use and interpersonal communication among international students. State University of New York in Partial Fulfillment of the Requirements for The Degree of Doctor of Philosophy, New York.

Karaoğlu, F. (2007). Yabancı Uyruklu Öğrencilerde Uyma Davranışı: Tömer Örneği. Yayımlanmamış yüksek lisans tezi. Ankara: Gazi Üniversitesi Sosyal bilimler Enstitüsü.

Karasar, N. (1995). Bilimsel Araştırma Yöntemi. Ankara: 3A Araştırma, Eğitim Danışmanlık Ltd. Şti.

Karasar, N. (2004). Araştırmalarda rapor hazırlama. Ankara: Hacettepe Taş Yayıncilik.

Khairullah, D. Z., \& Khairullah, Z. Y. (1999). Behavioural acculturation and demographic characteristics of Asian-Indian immigrants in the United States of America. International Journal of Sociology and Social Policy, 19(1/2), 5780.

Kim, C., Laroche, M., \& Tomiuk, M. A. (2001). A measure of acculturation for Italian Canadians: Scale development and construct validation. International Journal of Intercultural Relations, 25(6), 607-637. doi: 10.1016/S01471767(01)00028-1

Külebi, C. (1994). Ana Dili ve Yazın Öğretimi. İstanbul: Çağdas Yay.

Leong, F. T., \& Tata, S. P. (1990). Sex and acculturation differences in occupational values among Chinese-American children. Journal of Counseling Psychology, 37(2), 208-212. doi: 10.1037/0022-0167.37.2.208 
Meșe, G. (1999). Sosyal Kimlik ve Yaşam Stilleri. Yayımlanmamış Doktora Tezi. İzmir: Ege Üniversitesi Sosyal Bilimler Enstitüsü.

Montreuil, A., \& Bourhis, R. Y. (2001). Majority acculturation orientations toward "valued" and "devalued" immigrants. Journal of Cross-Cultural Psychology, 32(6), 698-719. doi: 10.1177/0022022101032006004

Özgüven, E. (1990). Yurtlarda Kalan Üniversite Öğrencilerinin Sağlık ve Psikolojik Sorunları. V. Ulusal Psikoloji Kongresi, Psikoloji-Seminer Dergisi Özel Sayısı, (8), 47-56.

Özhan, İ. (2006). Farklılaşmanın Özel Görünümler Olarak Çokkültürlülük ve Çokkültürcülük. Yayımlanmamış Yüksek Lisans Tezi. Ankara: Gazi Üniversitesi Sosyal bilimler Enstitüsü.

Palumbo, F. A., \& Teich, I. (2004). Market segmentation based on level of acculturation. Marketing Intelligence \& Planning, 22(4), 472-484. doi: $10.1108 / 02634500410542761$

Piontkowski, U., Florack, A., Hoelker, P., \& Obdrzálek, P. (2000). Predicting acculturation attitudes of dominant and non-dominant groups. International Journal of Intercultural Relations, 24(1), 1-26. doi: 10.1016/S01471767(99)00020-6

Quester, P. G., \& Chong, I. (2001). Validating acculturation models: The case of the Australian-Chinese consumers. Journal of Consumer Marketing, 18(3), 203-218. doi: 10.1108/07363760110392958

Romero, A. J., \& Roberts, R. E. (2003). Stress within a bicultural context for adolescents of Mexican descent. Cultural Diversity and Ethnic Minority Psychology, 9(2), 171-184. doi: 10.1037/1099-9809.9.2.171

Sam, D. L. (1992). Psychological Acculturation of Young Visible Immigrants. Migration World Magazine, 20(3), 21-24.

Sam, D. L., \& Berry, J. W. (1995). Acculturative stress among young immigrants in Norway. Scandinavian Journal of Psychology, 36(1), 10-24. doi: 10.1111/j.1467-9450.1995.tb00964.x

Sam, D.L., \& Berry, J.W. (1995). Acculturative Stres Among Young Immigirants in Norway. Scandinavian Journal of Psychology, 36, 10-24.

Şeker, B. D. (2006). Kente göç etmiş bir örneklemde kültüre uyum (kültürlenme) süreçleri. Uluslararası İnsan Bilimleri Dergisi, 3(2).

Tanaka, T., Takai, J., Kohyama, T., Fujihara, T., \& Minami, H. (1994). Social networks of international students in Japan: Perceived social support and relationship satisfaction. Japanese Journal of Experimental Social Psychology, 33(3), 213-223. doi: 10.2130/jjesp.33.213

Tekeli, İ. (1982). Kentleşme Yazıları. Ankara: Turhan Kitabevi. 
Tezcan, M. (1995). Sosyoloji, Temel Kavramlar. Ankara: Feryal Matbaası.

Tomich, P. C., McWhirter, J. J., \& Darcy, M. U. (2003). Personality and international students' adaptation experience. International Education, 33(1), 22-39.

Toyokawa, T., \& Toyokawa, N. (2002). Extracurricular activities and the adjustment of Asian international students: A study of Japanese students. International Journal of Intercultural Relations, 26(4), 363-379. doi:10.1016/S0147-1767(02)00010-X

Turhan, M. (1980). Atatürk İlkeleri ve Kalkınma. İstanbul: Yağmur Yayınlar1.

Üstündağl1, E. (2009). Balkan Göçmenlerinin Türkiye’de Kültürleşmeleri Sürecinde Türk Tüketim Kültürüyle Olan Etkileşimi. Yayımlanmamış Yüksek Lisans Tezi. İzmir: Ege Üniversitesi Sosyal Bilimler Enstitüsü.

Yeşildağ, E. (2008). Avrupa'da Yaşayan Türklerin Aile Yapıları ve Entegrasyon (Uyum) Sorunları (Avusturya Örneği). Yayımlanmamış Yüksek Lisans Tezi, Afyon: Kocatepe Üniversitesi Sosyal Bilimler Enstitüsü.

Zea, M. C., Asner-Self, K. K., Birman, D., \& Buki, L. P. (2003). The Abbreviated Multidimentional Acculturation Scale: Empirical validation with two Latino/Latina samples. Cultural Diversity and Ethnic Minority Psychology, 9(2), 107-126. doi: 10.1037/1099-9809.9.2.107 
